\title{
A simple model based on known plant defence reactions is sufficient to explain most aspects of nodulation
}

\author{
Robert B. Mellor ${ }^{1,2,3}$ and David B. Collinge ${ }^{1}$ \\ ${ }^{1}$ Department of Plant Biology, Royal Veterinary and Agricultural University, Thorvaldsensvej 40, \\ DK-1871 Frederiksberg C, Denmark \\ ${ }^{2}$ Botanical Institute, University of Basel, Basel, Switzerland
}

Received 23 May 1994; Accepted 15 September 1994

\begin{abstract}
We present the following hypothesis; that lipooligochitin Nod-factors can act in an elicitor-like fashion inducing, amongst other effects, a plant chitolytic enzyme, capable of hydrolysing the oligochitin chain of the Nod-factor. Decorative groups on the oligochitin chain, e.g. sulphate, may confer partial resistance to hydrolysis upon particular Nod-factors. After entry into the plant, Nod-factor synthesis must be downregulated in order to avoid further, unwanted, elicitation and the consequent abortion of the symbiosis. The plant-derived compounds inhibiting the synthesis of bacterial Nod-factors are limiting in root tissue, leading to residual elicitation and the abortion of infection thread formation. Nod-gene anti-induction is, furthermore, inactivated by both light and nitrate, thus contributing to the inhibition of nodulation under these conditions. In nitrogen-fixing nodules, the bacteroids are exposed to both nod-gene inducing and repressing compounds. The slow accumulation of Nod-factors within the peribacteroid space eventually results in the elicitation of phytoalexin synthesis and nodule senescence.
\end{abstract}

Key words: Chitinase, elicitors, Leguminosae, Nod-factors, Rhizobium, symbiosis.

\section{Introduction}

By virtue of their immobility, terrestrial plants have had to develop an extraordinary genetic and metabolic plasticity enabling them to deal with diverse environmental stresses. Such stresses include their habitual encounters with soil, water, or air-borne microbes. Apparently almost all plants exhibit the ability to distinguish between pathogenic and symbiotic contacts, since they readily enter into symbiotic associations (for example, over $95 \%$ of all vascular plants can enter into intimate symbioses with fungi, Newman and Reddell, 1987), but are simultaneously able actively to rebuff pathogenic challenges (Collinge et al., 1994). There may be similarities between pathogenic and symbiotic modes of infection and at least some elements of the molecular recognition mechanisms may be common to both cases. The end results of the recognition sequences are, however, very different. Pathogenic attack leads to cell necrosis and cell death, whereby, for example, symbiotic nodule formation results in nitrogen-fixing bacteroids encapsulated in apparently healthy leghaemoglobin-containing plant tissue (Staehelin et al., 1992a).

In the following sections, we examine the phenomenon of the nitrogen-fixing root nodule symbiosis (between rhizobia and legume plants) in the light of known plant responses to antagonistic microorganisms generally. This includes the production of phytoalexins and their (often bio-active) precursors, the anti-microbial hydrolases glucanase and chitinase, and the action of these upon bacterial components, especially the action of plant chitinase(s) on Nod-factors. We also analyse the methods whereby the plant can influence the bacterial synthesis of Nod-factors and factors affecting these control mechanisms. The result is a model which explains almost all facets of nodulation.

\section{Terms and definitions}

Whilst not wanting to introduce new expressions into the literature, the following terms will be used in specific

\footnotetext{
${ }^{3}$ To whom correspondence should be addressed in Denmark. Fax: +4535283310.
} 
ways for the purposes of this paper. Nod-on; any low molecular weight substance, usually plant-derived, capable of inducing expression of the rhizobial common nodgenes when present at low concentrations. Nod-off; as above, but capable of inhibiting or reversing the above process (for further explanation, see Section 7). Chitinase; an enzymic activity capable of hydrolysing oligochitin chains of length equal to, or greater than, $3 \mathrm{~N}$-acetylglucosamine units. Elicitors; products, often of microbial origin, capable of inducing one or several responses in plants, all of which are associated with the 'defence response' (sometimes called 'resistance response' or 'pathogenesis response', e.g. Lucas et al., 1985; Collinge and Slusarenko, 1987; Collinge et al., 1994). The defence response can include the accumulation of phytoalexins (Ouchi, 1983; Dixon, 1986; Nicholson and Hammerschmidt, 1992; Collinge et al., 1994), peroxidase activity (Svalheim and Robertsen, 1990), glucanase activity (Mauch et al., 1988), chitinase activity (Collinge et al., 1993) and may be associated with the production of the stress hormone ethylene which, in turn, can provoke certain of the above effects (Boller, 1988). Elicitors can be either of exogenous (i.e. microbial), or endogenous origin (i.e. derived from the plant, for example, its own cell wall). Elicitors are fortuitously recognized by a host receptor; thus any elicitor may be of limited host range (Collinge et al., 1994; Ebel and Cosio, 1994). Salicylic acid and jasmonic acid, which are often treated as elicitors, are not considered as such here, but rather as hormones. Hypersensitive response ('HR'); here the definition of Klement (1982) is used, with the following comments; firstly, it is almost impossible to prove that a localized response, for example, as noted recently in front of several growing infection threads (Vasse et al., 1993), is a hypersensitive response because the increased enzyme or product levels are diluted out by surrounding, nonreacting, tissue. Secondly, as shown in Table 1 , even in those $\mathrm{Fix}^{-}$nodules accumulating higher levels of defence response-associated activities, the absolute amounts of phytoalexin and chitinase accumulated are far less than those recorded for classical hypersensitive responses. In short, caution should be exercised when using this expression, especially in connection with nodules. It should also be noted that the hypersensitive response is not

Table 1. Levels of some plant defence reactions in control and infected soybean tissue

\begin{tabular}{lllll}
\hline & Roots & Fix $^{+}$nodules & Fix ${ }^{-}$nodules & Pathogen/HR \\
\hline $\begin{array}{c}\text { Phytoalexin } \\
(\mu \mathrm{g} / \mathrm{g} \mathrm{FW})\end{array}$ & $0.6 \pm 0.2^{1}$ & $5 \pm 3^{1}$ & $50-200^{1}$ & c. $1000^{2}$ \\
$\begin{array}{c}\text { Chitinase } \\
\text { (nkat } / \mathrm{g} \mathrm{FW})\end{array}$ & $0.4^{3}$ & $1.5-2.5^{3}$ & $3-4^{3}$ & c. $550^{4}$ \\
\hline
\end{tabular}

Data collated from: 1, Werner et al. (1985). 2, Osman and Fett (1983). 3, Staehelin et al. (1992a). 4, Metraux and Boller (1986). the automatic consequence of elicitation (Jakobek and Lindgren, 1993).

\section{Plant defence reactions in nodulation}

\section{(1) Properties of Nod-factors}

The molecular structure of a typical Nod-factor was first presented by Lerouge et al. (1990) and has recently been reviewed by Vijn et al. (1993). The molecule consists of a backbone of saccharide residues attached to a lipid tail. This has led to the term 'lipo-oligosaccharides' to describe Nod-factors. The saccharide backbone may be further decorated with additional groups, e.g. sulphate (for reviews see Verma, 1992; Vijn et al., 1993). A closer inspection of the sugar residues involved reveals that they are $\mathrm{N}$-acetyl-glucosamine. Thus the Nod-factor molecule could more correctly be called a 'lipochitosan'.

It is central to our hypothesis that the oligochitin portion of Nod-factor molecules behaves as oligochitins are known to do in other systems, that is, they can be perceived by plant cells in an elicitor-like fashion and that they are also substrates for plant hydrolases. The contention that Nod-factors may be described as elicitors comes from the following considerations; they cause alkalinization of the medium in tomato cell-culture systems in a fashion similar to that caused by known elicitors, and this effect can be blocked by pre-treatment of the cells with elicitor, exactly as the effect of oligochitin elicitor can also be blocked by Nod-factor (Staehelin et al., 1994a); they cause phytoalexin (capsidiol) accumulation in green peppers (W.J. Bell and R.B. Mellor, unpublished observations) and phytoalexin response in homologous legume suspension cultures (Savoure et al., 1994); they induce peroxidase activity on host legume roots (Salzwedel and Dazzo, 1993); they induce chitinase activity after being applied to host and non-host roots (Staehelin et al., 1994b; Schultze et al., 1993) and nonhost leaves (Nielsen et al., 1994b). It should, however, be noted that the results from the tomato cell assay system reveal Nod-factors to have a milder action (i.e. less alkalinization per mole substance) than many classical elicitors (compare Staehelin et al., 1994a with Felix et al., 1993). The second contention, that Nod-factors are substrates for chitinases, has been proven using a variety of host and non-host derived chitinases both in vitro (Staehelin et al., 1992b, 1994a) and in vivo (Staehelin et al., 1994b; Schultze et al., 1993).

Recourt et al. (1992) state that 'Rhizobial signal molecules are only recognized by a host plant, whereas elicitors are recognized by various non-host plants'. Nod-factors, however, are perceived by such diverse tissues as tomato (Staehelin et al., 1994b), carrot (De Jong et al., 1992) and both host and non-host legume roots (Staehelin et al., $1994 a, b)$. The difference between host and non-host 
response lies in the timing of the elicitation response (see Section 2, Fig. 1, Staehelin et al., 1994a). Thus the statement of Recourt et al. (1992) should be modified to 'Rhizobial signal molecules can be perceived by a wide range of plants, and elicit their own rapid hydrolysis. In those cases (host plants) where elicitation is delayed, the Nod-factor has a long enough half-life for the plant to experience other biological effects, including root-haircurling .... In this respect it is interesting to note that appropriate Nod-factors alone are sufficient to induce structurally complete nodular structures on Medicago sativa (Truchet et al., 1991) and Glycine soja (Stokkermans and Peters, 1994), but not, or only to an incomplete extent, on other host plants (Spaink et al., 1991; Sanjuan et al., 1992; Mergaert et al., 1993). We thus suggest that Nod-factors are capable of inducing nodular structures on all host plants, but that the developmental sequence can be interrupted by elicitation and hydrolytic removal of the active Nod-factor in some cases. It may be possible to overcome the 'chitinase barrier' and directly implant Nod-factors in host and non-host plant cells by, for example, microsurgical techniques, providing that wound responses can be minimized.

The elicitor activity of Nod-factors can be blocked by pre-treatment of the plant tissue with oligochitin elicitors (Staehelin et al., 1994a), and both eliciting and root hair curling activity are lost after hydrolysing the Nod-factors oligochitin backbone with chitinase (Staehelin et al., $1994 b$ ). Thus we propose that inhibitors of the cascade pathway induced by oligochitin elicitors, for example, the protein kinase inhibitor K-252a (Felix et al., 1991), should also block root hair curling by Nod-factors. However, the biological activity of Nod-factors does not reside in either their elicitor oligochitin backbone or lipid tail alone. Lipid tails with only one or two sugars in the backbone are inactive in curling root hairs (Staehelin et al., 1994b). It should also be noted that simple eliciting oligochitins like chitobiose, chitotriose and chitotetrose do not curl root hairs, that is, it is the combined effect of the elicitor backbone and the lipid tail which together are responsible for the biological effects of Nod-factors on plants. It is currently unknown whether lipases are involved in nodulation.

More speculative are the physical consequences of the Nod-factors lipid tail. Hirsch (1992) has already speculated that this may well cause it to associate with the bacterial membrane, leaving the eliciting oligochitin moeity exposed on the bacterial surface. Hubbell (1970) and Yao and Vincent (1976) purified exopolysaccharides (EPS) from bacterial pellets and found root-hair-curling activity co-purified with EPS. Although Nod-factors are traditionally purified from the supernatant of bacterial cultures (Schultze et al., 1992; Spaink et al., 1991; Lerouge et al., 1990), the above speculation could easily be checked by comparing the yield of Nod-factor from culture super- natant and pellet. If the majority of the Nod-factor is associated with the bacterium, then this implies that the plant reactions associated with nodulation could be extremely localized, an aspect discussed further below (Section 5 on the specificity of nodulation).

\section{(2) The autoregulation of nodulation}

In this section we consider the insensitivity of previously inoculated (but not yet nodulated) plants to subsequent symbiotic infection (Bhuvaneswari et al., 1980; CaetanoAnollés and Gresshoff, 1991). The regulation of the number of nodules formed in respect to the number of bacterial infections, as well as the sensitivity of nodulation to pre-formed nodules (Bauer, 1981, and references therein) will be considered in the second part in the section on nod-offs (Section 7).

Part of the hypothesis presented here states that the autoregulation of nodulation is achieved by the bacterial Nod-factor eliciting a temporary plant response consisting of, amongst other factors, an enzyme activity capable of hydrolysing the oligochitin backbone of Nod-factors (this enzyme is thus by definition a chitinase), thus robbing the Nod-factor of further biological activity. This concept is supported by the data from both Schultze et al. (1993) and Staehelin et al. $(1994 a, b)$ and is summarized in Fig. 1 (adapted from Staehelin et al., 1994b). Here it can be seen that treatment of heterologous (non-host) roots with a Nod-factor results in the rapid induction of an enzyme activity capable of hydrolysing the oligochitin moiety of the Nod-factor. On the homologous host, an even more dramatic induction, and hydrolysis of the Nodfactor, took place. In the case of the homologous system, however, the induction was delayed, showing a lag time of about 4-6 h. Pierce and Bauer (1983) showed that the autoregulatory response is very rapid, a matter of $3-6 \mathrm{~h}$. Thus we hypothesize here that, within this period of time, the symbiotic bacteria have been able to penetrate the host plant (Bieberdorf, 1938; Callaham and Torrey, 1981; Turgeon and Bauer, 1982), and that their Nod-factor production has either started to be down-regulated (see Section 7) or that they are transiently in a protected environment of lowered elicitability (the infection sac or infection thread). Outside the plant, however, a dramatic induction of chitinase activity has been achieved. The Nod-factors produced by subsequent bacteria will therefore be hydrolysed, a treatment removing their biological activity (Staehelin et al., 1994b) and secondary infection can no longer take place. Thus the plant controls the biological effects of the Nod-factor(s) by determining their half-life by means of chitinase(s). It would be interesting to see to what extent this effect is systemic, for example, does the application of Nod-factor (or ethylene or elicitor) on one side of a split-root system induce chitinase on the other side? It may also be possible 
to study the effects of Nod-factor on infection thread membrane using, for example, Andira nodules, where nitrogen-fixing bacteria are retained within branched thread structures (de Faria et al., 1986).

Only pre-emergent root hairs of soybean are susceptible to nodulation (Calvert et al., 1984) and it may be useful to check, by staining with labelled antibodies directed against chitinases, if this tissue specifically contains differing levels of chitinases, and if these same types of chitinases are present in the appropriate, infectible, areas of other legumes such, as clover and pea, where mature root hairs are susceptible to nodulation.

Nod-factors often exhibit additional substitutions (often called 'decorations'), for example, sulphate (Roche et al., 1991) or extra acyl and sugar (Sanjuan et al., 1992) groups. These decorations can influence the stability of the Nod-factor towards plant chitinases (Schultze et al., 1993; Staehelin et al., 1994a, b). This implies that the above situation can be seen as an interplay between the symbiotic partners, on one side the degree and timing of elicitation and, on the other side, the resistance of the Nod-factor to chitinolytic attack, in those cases where elicitation is significant. This situation is summarized in Fig. 2.

It should, however, also be noted that whilst the Nodfactor induced and Nod-factor hydrolysing enzyme is, by definition, a chitinase, its substrate specificity (Staehelin et al., 1994b) clearly shows that it does not belong to the classical ethylene-induced, defence-related type I chitinases (Collinge et al., 1993). This novel chitinase does, however, act in concert with chitinases similar to the classical ethylene-induced chitinases (Staehelin et al., $1992 b, 1994 a$ ) to inactivate Nod-factors (Staehelin et al., $1994 b$ ). The reaction products indicate that class III or class IV chitinases could be candidate isoenzymes (com-

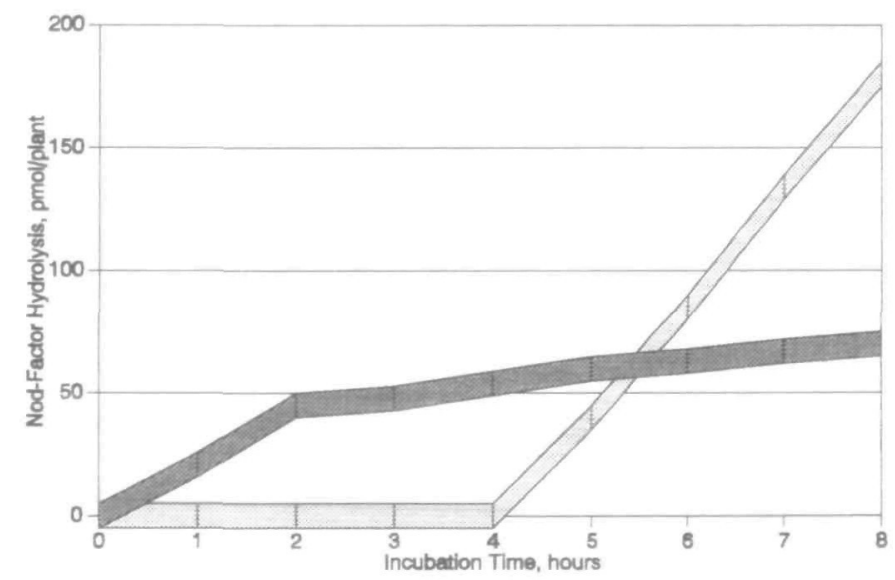

Fig. 1. Total chitolytic activity, using Rhizohium meliloti NodRmV(S) Nod-factor as substrate, on intact host (Medicago sativa) (light, behind) or non-host (Vicia sativa) (dark, front) roots. Redrawn from Staehelin et al. (1994b). Band width $=5 \%$ variation.

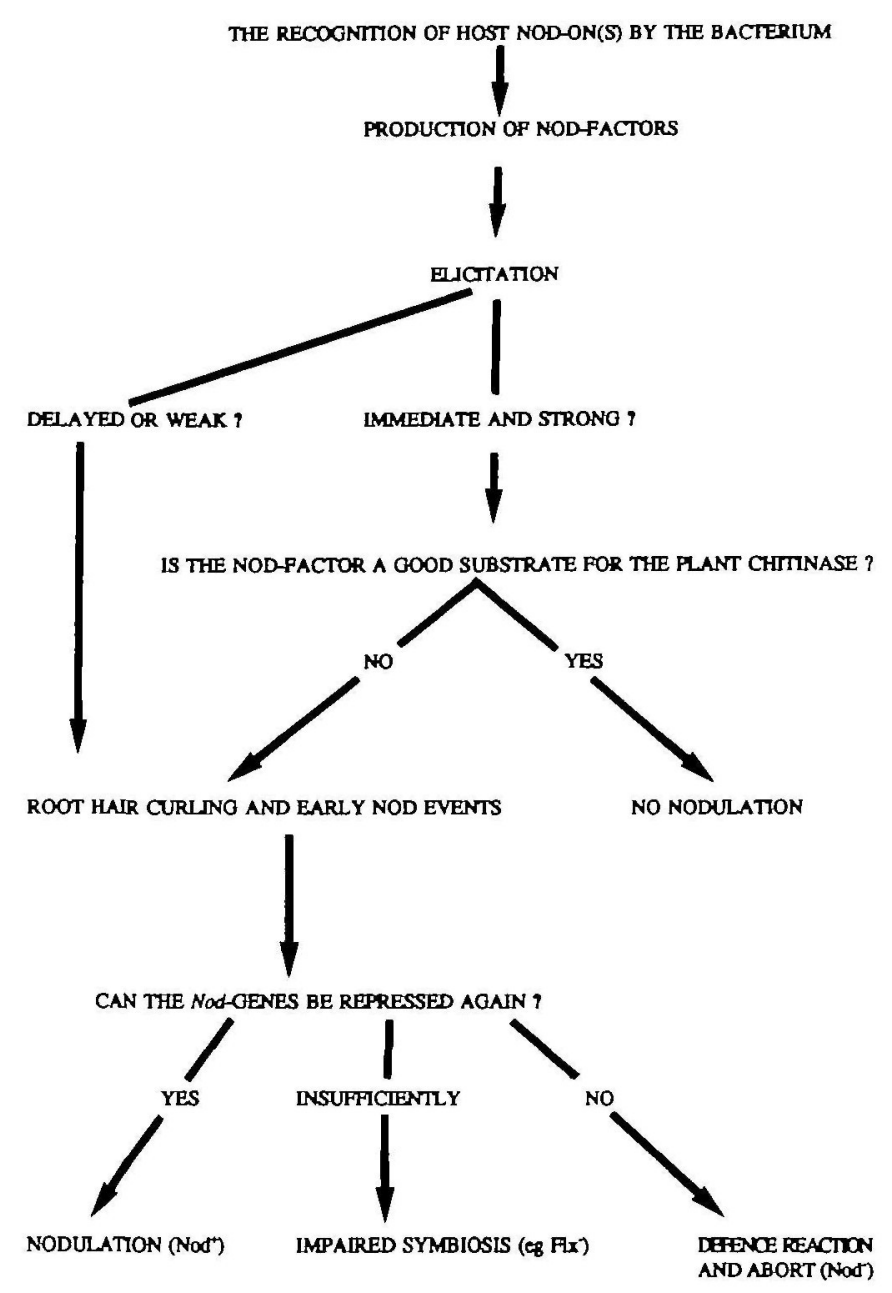

Fig. 2. Simplified scheme of events determining the establishment of a functional symbiosis (effective nodulation). Please note that 'elicitation' is a combination of both the intrinsic elicitor activity of the Nod-factor and the sensitivity of the plant to elicitors.

pare Nielsen et al., 1993, 1994a, with Staehelin et al., 1994b).

All plants tested to date possess multiple chitinases and it would thus be most interesting to investigate the effects of Nod-factors on genetically modified non-host plants incapable of producing various chitinases (or indeed, transgenic host plants over-expressing chitinases). This may have some bearing upon the synthesis of artificial symbioses.

\section{(3) The Jan and Cnb phenomena}

The 'jamming of nodulation' (Jan, Van Brussel et al., 1993) and 'competitive nodulation blocking' (Cnb, Dowling et al., 1988) phenomena can be considered as extensions of the autoregulation of nodulation. In the Jan effect, the pre-treatment of host roots with pure Nod-factor abolishes nodulation by subsequent, symbiotic bacteria. In the case of Cnb, pre-treatment of plants with an incompatible symbiont blocks subsequent nodula- 
tion by the true microsymbiont (e.g. the prior treatment of Afghanistan pea with Rhizobium leguminosarum $\mathrm{PF}_{2}$ strain, itself a non-nodulator on this plant, blocks nodulation by the symbiotic $R$. leguminosarum TOM strain, Dowling et al., 1988). In the light of the above hypothesis, this can be explained by postulating that the Nod-factors from both the correct symbiont (in the case of Jan) or the false symbiont (in the case of $\mathrm{Cnb}$ ) transiently elicit host chitinase activity. This would then result in the hydrolysis of the Nod-factors synthesized by the subsequently-added, homologous, microsymbiont. This could be confirmed by simple chitinase assays.

The Cnb phenomenon will, however, probably not be reproducible with all bacterial and plant combinations. The data of Staehelin et al. (1994a), imply that Nodfactors of five $\mathrm{N}$-acetyl-glucosamine residues length are up to 100 -fold better elicitors than those with only four units length. Conversely, some Nod-factors, especially those of four $\mathrm{N}$-acetyl-glucosamine units length and without additional substitutions, are exceptionally susceptible to hydrolysis by chitinases (Staehelin et al., 1994b).

From the above discussion (Sections 1, 2 and 3) it can be seen that nod-genes are acting in a fashion analogous to avirulence genes. This comparison is supported by the Nod-factors (A) effects as an elicitor on non-host plants, (B) delayed effect as elicitor on host plants, and (C) effects as elicitor causing non-symbiotic bacteria to interfere with homologous symbiotic interactions.

\section{(4) Ethylene and nodulation}

Since the transgenic hosts expressing different levels of chitinase mentioned at the end of Section 2 are not yet available, one must glean more circumstantial evidence from biochemical sources for a role for chitinase in nodulation. In addition to its role in various developmental processes, ethylene is generally implicated in the defence reactions of plants towards various microorganisms, especially pathogens (Collinge et al., 1994) and the induction of chitinases in particular (Collinge et al., 1993).

The ethylene treatment of peas induces chitinase in the roots (Vignutelli, 1991, and Fig. 3). Ethylene-treated peas no longer nodulate (Goodlass and Smith, 1979; Lee and LaRue, 1992b). The treatment of soybean with ethylene does not induce chitinase in the roots (Vignutelli, 1991, and Fig. 3) and such plants are normal nodulators (Vignutelli, 1991). This could be interpreted as the first evidence, albeit indirect, for the involvement of chitinase in nodulation, although it is not known at which level the chitinase could act; the extracellular hydrolysis of Nod-factors or in aborting infection thread formation. In order to clarify this point, root-hair-curling assays could be carried out using purified Nod-factors on ethylenetreated plants. It is interesting that reports from LaRue's laboratory (Lee and LaRue, 1992a, b) indicate that

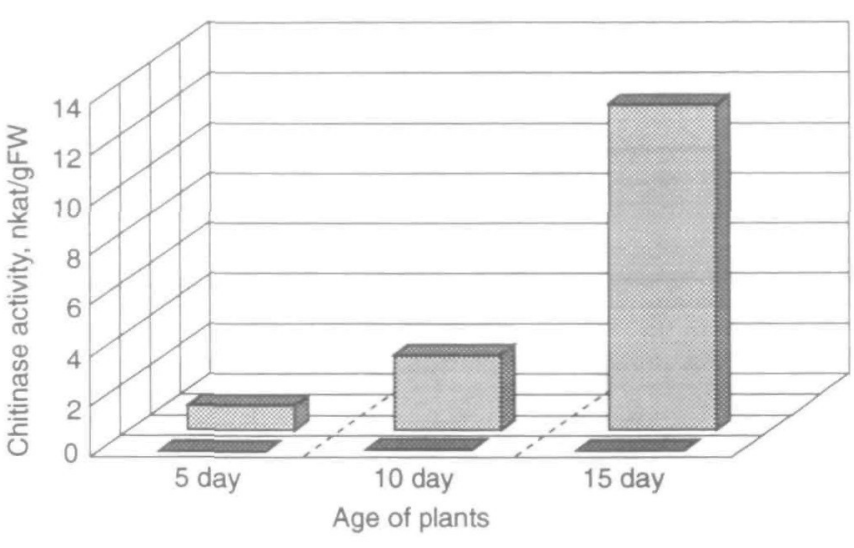

Fig. 3. Induced chitinase activity in soybean (front) or pea (behind) roots. Plants of various ages were treated with $100 \mathrm{ppm}$ ethylene for $48 \mathrm{~h}$ and the chitinase assayed $24 \mathrm{~h}$ after removing the ethylene. Control (non-ethylene-treated) levels did not exceed 0.5 (soybean) or 1.5 (pea) nkat/gFW. Data taken from Vignutells (1991).

ethylene inhibits the development of pea nodule primordia rather than blocking root hair curling. The lack of primordia formation implies a lack of Nod-factor at a stage of infection later than root hair curling. This is interpreted as being due to hydrolysis by ethylene-induced class I chitinases (Staehelin et al., 1992b), whereas putative class III or class IV chitinases are involved in abolishing root hair curling after elicitation by heterologous Nod-factors (Staehelin et al., 1994b, and Section 2).

A more elegant approach for studying the role of endogenous ethylene in nodulation could involve the use of mutants affected in ethylene biosynthesis. However, it should be noted that an analogous study of the interaction between Arabidopsis thaliana and bacterial pathogens showed that race specificity was unaffected in the ethylene biosynthesis mutants (Bent et al., 1992).

\section{(5) The specificity of nodulation, a role for lectins?}

The specificity of nodulation cannot be explained by any single factor, but only by a series of events. Firstly, the host plant must export the appropriate nod-on compound(s). This must be perceived by the bacterium, which responds by inducing the genes coding for the synthesis of an appropriate Nod-factor. The 'wrong' Nod-factor may elicit its own hydrolysis (Staehelin et al., 1994b) and thus root hair curling etc. will not take place. The importance of physical distances and concentration gradients in nodulation has already been explained by Phillips (1992). The concept of 'ecological chemistry' (Phillips et al., 1990) is quite central since the bacterium must be present at the correct portion of the host root (the infectible zone) not only at the right time (before elicitation due to other non-symbionts or pathogens), but also the bacterium must be equipped with the correct number of Nod-factor molecules (too few will induce no response, whilst too many may induce the elicitation of 
a defence response). There may be a sequence of several nod-on compounds (and also nod-off compounds, including nod-ons acting as functional nod-offs, see Section 7), which have different degrees of inducer (or anti-inducer) activity, in the rhizosphere at various distances from the host (Hartwig et al., 1989). After entry into the host, the individual bacteria must recognize a further array of plant nod-off compounds (see Section 7) and down-modulate Nod-factor synthesis accordingly (both temporally and spatially).

Obviously a large part of specificity is determined by the host's reaction to different Nod-factors. In particular, why do Nod-factors from homologous symbionts cause a delayed elicitation (Fig. 1)? The answer to this question is unknown, but one interesting speculation (Hirsch, 1992 ) is that host molecules can recognize Nod-factors, bind to them and thus temporarily mask them from host elicitor-receptors. This binding could be either enhanced or restricted by adjacent EPS molecules on the bacterial surface (Philip-Hollingsworth et al., 1989), or neighbouring LPS molecules (Perotto et al., 1994). Halverson and Stacey (1984) reported on a plant-derived proteinaceous factor involved in the nodulation of soybean by Bradyrhizobium japonicum HS 111, a 'slow' nodulator. Removal of this factor by protease treatment resulted in no nodulation. Could this have been a protein which was masking the Nod-factor to prevent it from being recognized by plant elicitor-receptors? Furthermore, could this putative host Nod-factor-masking protein possibly be a soluble extracellular lectin (proteins binding reversibly to sugars are, by definition, lectins)? If Nod-factors are postulated to be bacterial membrane components (see Section 1 and Hirsch, 1992), then this speculation could not only provide an explanation of the delayed elicitation phenomenon (by lectin-binding temporarily masking the oligochitin backbone), but could also clarify a good deal of the literature concerned with the role of lectins in nodulation. This includes data that bacterial strains having no lectin-binding sites suddenly acquired them when cultured in conditions inducing nod-gene expression (e.g. with host roots or root exudates, Bhuvaneswari and Bauer, 1978), and why transgenic clover roots expressing pea lectin can nodulate with both the pea and clover microsymbionts (Diaz et al., 1989). Thus it would be interesting to see the results of lectin anti-sense mRNA experiments using host plants (i.e. reducing nodulation), as well as assaying for root hair deformations in transgenic non-host plants expressing lectin genes.

\section{(6) Bacterial nodulation-deficient exopolysaccharide (exo) mutants}

The above sections have dealt with lipochitosan Nodfactors and their characteristic of being both an elicitor of, and substrate for, chitinase(s). There are also aspects of nodulation, however, which cannot be explained through the properties of Nod-factors. One such area involves bacterial exo mutants (Borthakur et al., 1988; Niehaus et al., 1993).

(Exo)polysaccharides (EPS) from Rhizobium may also possess signal functions, since Rhizobium meliloti mutants which fail to produce EPS (exo $)$ induce only empty nodules on Medicago (Leigh et al., 1985). Recently it was found that a specific oligosaccharide form of succinoglycan is required for alfalfa root nodulation and that exogenously applied succinoglycan restored nodule invasion to exo ${ }^{-}$mutants on Medicago (for review see Leigh and Walker, 1994). Parallel to chitinases, $\beta$-1,3-glucanases are important enzymes of the defence reaction in hostpathogen interactions (Mauch et al., 1988). To date, however, data are lacking about the role of these glucanases during nodulation. Glucanases, however, are good candidates to interact with succinoglycans. The succinoglycan molecule from $R$ meliloti is partly linked by beta 1-3 glycosidic bonds, thus these enzymes could cleave this oligosaccharide, a parallel to the chitinase-mediated cleavage of Nod-factors. Thus a plant $\beta$-1,3-glucanase may be elicited as a response to a challenge by either succinoglycan or Nod-factor and cleave the succinoglycan, either inactivating its signal character (as in the case of the Nod-factors) and/or releasing one or more biologically active cleavage product(s) (Thanh Van et al., 1985), including suppressins (Basse et al., 1993; Oku et al., 1993). This interpretation is further supported by two sets of circumstantial evidence. Firstly, the exo/nodulation phenomenon is limited to interactions resulting in cylindrical (indeterminate) nodules (Hotter and Scott, 1991), where infection events (and thus the need for suppression) are continuous. Secondly, there are recent indications that low molecular weight succinoglycan degradation products are indeed required for nodulation (Leigh and Walker, 1994). Thus a second defence response hydrolase, a plant glucanase, may also play a role in symbiotic specificity.

\section{Regulation of Nod-factor production}

\section{(7) The importance of nod-offs}

After coming into close contact with the plant, and subsequent penetration into the plant tissue, bacterial nod-gene expression is reduced (Schlaman et al., 1991). Bearing in mind the eliciting nature of the products of the nod-gene-encoded enzymes, the Nod-factors, this down-modulation may well be essential in order that the invading bacterium can avoid eliciting significant host defence reactions. Certainly bacteria constitutively overexpressing the common nod-genes are unable to nodulate (Knight et al., 1986). The exact extent to which Nodfactor production must be repressed (i.e. what is signific- 
ant) probably depends on various factors. These include the elicitability of the host in question, and also which defence responses are present and what concentration of the various plant defence molecules each bacterial symbiont can withstand. Thus the degree of residual Nod-factor production may well differ slightly between host-bacteria combinations (for example, from the data presented in Section 4, one would expect pea to be more sensitive to elicitation than soybean, implying that soybean bacteroids may be 'allowed' more residual Nod-factor synthesis than pea bacteroids). In order to explain the down-regulation of the nod-genes in symbiotic bacteroids, we have concentrated on the possible role of nod-offs.

We prefer the term nod-off to terms like 'anti-inducer' or 'repressor' because the latter two may signify competition with nod-ons (inducers) for recognition by NodD protein(s), and we think that until this competition is proven, then the terms repressor or anti-inducer could be misleading. It should be stressed that most nod-offs reported to date are simply commercially-available compounds leading to a reduced $\beta$-galactosidase activity when added to an indicator bacterium containing a nod-lac $Z$ fusion construct and appropriate inducer. Their mode of action is therefore totally unknown. Indeed, from the molecular structures presented in Fig. 4, it is hard to imagine, for some nod-offs, e.g. acetosyringone, that they could possibly compete with nod-ons for specific recognition or binding to NodD protein(s). Their mode of action is presently speculative, but may be quite different, ranging from inhibiting the uptake of nod-ons by bacteria, to inducing independent or semi-independent genetic repression systems. Suitable candidates may include the nod $\mathrm{VW}$ and nolA genes.

The strongest argument against the involvement of nod-offs in the down-regulation of nod-genes comes from work by Lugtenberg's group (Schlaman et al., 1991). In this work, an unidentified nod-off was extracted from Vicia nodules which could down-regulate expression of a nod $A-l a c Z$ fusion construct. When this plasmid construct was supplemented with further plasmids containing constitutively-expressed nodD genes, the in vitro-cultured bacteria containing the multi-copy plasmids were no longer so susceptible to the nod-off, whereas their nodgene expression as bacteroids (in this case, in the Fix ${ }^{-}$ nodules) was repressed as in the wild type. Despite this evidence, we still adhere to the hypothesis that nod-offs are important in down-regulating nod-gene expression. This view rests not only on the considerations presented in Sections 8 and 10 , but also upon a critique of the above experiment, which can be explained by one, or a combination of several, of the following considerations. Firstly, it is possible that the multiple-construct in the experiment (Schlaman et al., 1991) described above was susceptible to the effects of nod-off, but at higher nod-off concentrations, outside the range tested. Certainly, the concentrations of nod-off which can be achieved by the plant in the appropriate subcellular compartment(s) during nodulation, is unknown. Secondly, the nodules formed were ineffective, i.e. not normal symbiotic nodules. Such nodules often exhibit raised levels of chitinase (Staehelin et al., 1992b). Thus the plant may have been able to compensate for a lowered rate of repression of Nod-factor production by using an induced chitinase. Thirdly, since the mechanisms of nod-off action are unknown, it is possible that nodule nod-offs could, for example, be involved in inducing or activating the bacteroid-specific repressor protein needed to down-regulate the expression of common nod-genes in bacteroids, as reported by Schlaman et al. (1992). Thus the results of Schlaman et al. (1991) are not an argument against the role of nod-offs per se, but rather indicate that a transition occurs between bacteria in the free-living state and in the symbiotic bacteroid state. Wild-type bacteria respond to nod-offs in both states, but bacteria carrying multicopy plasmids containing constitutively-expressed nodD were amenable to the effects of nod-offs only in the bacteroid state (indeed, the same mechanisms may be operating in all cases, but were only detectable in the bacteroids with powerful nodD expression). Conversely, if the appearance of a repressor protein (Schlaman et al., 1992) is independent of nod-off concentration, then this may indicate that some bacteria possess an alternative mechanism for cases where nod-offs are ineffective. This supports our impression that nodulation involves an anastomosing network of major and back-up signal pathways, rather than a linear signal chain.

Nod-off activities have been reported from the pea (Firmin et al., 1986), clover (Djordjevic et al., 1987), alfalfa (Peters and Long, 1988), Vicia (Schlaman et al., 1991), and soybean (Mellor and Rosendahl, 1994) systems (Table 2; Fig. 4). Schlaman et al. (1991) reported that a methanolic extract of Vicia nodules exhibited nodoff activity, but, unfortunately, the causative compounds have not been characterized. In a recent report using the soybean system (Mellor and Rosendahl, 1994), the major nod-gene repressor was proposed to be riboflavin. This is in agreement with earlier results indicating the involvement of riboflavin as a factor in symbiotic efficiency (nodule riboflavin content and nitrogen-fixing activity being positively correlated, Pankhurst et al., 1974; Fehling et al., 1992). The nod-off riboflavin is thought to be of host origin since bacterial riboflavin auxotrophs form nitrogen-fixing, riboflavin-containing nodules (Pankhurst et al., 1974). It should be stressed here that nod-offs have hardly been studied and that further research may well reveal that the host plant possesses a whole battery of such compounds.

A further level of refinement is added by various nodD genes within one bacterium being activated by different 
Table 2. Some known nod-ons and nod-offs for rhizobial and bradyrhizobial nodulation genes

\begin{tabular}{|c|c|c|}
\hline & Nod-ons & Nod-offs \\
\hline$R$ trifolit & $\begin{array}{l}\text { Flavones with } \mathrm{OH} \text { at } \\
\text { the } 7 \text { position, e.g. } \\
7,4^{\prime} \text { diOH flavone }\end{array}$ & $\begin{array}{l}\text { Coumarins, e.g. } \\
\text { umbelliferone } \\
\text { Isoflavones, e.g. } \\
\text { formononetin }{ }^{1}\end{array}$ \\
\hline$R$ leguminosarum & $\begin{array}{l}\text { Flavones, e.g. } \\
\text { apigenin } \\
\text { Flavanones, e.g. } \\
\text { hesperitin }^{2}\end{array}$ & $\begin{array}{l}\text { Isoflavones, e.g } \\
\text { daidzein, genistein } \\
\text { Flavonols, e.g. } \\
\text { kaempferol } \\
\text { Acetophenones, e.g. } \\
\text { acetovanillone, } \\
\text { acetosyringone }\end{array}$ \\
\hline B. japonicum & $\begin{array}{l}\text { Isoflavones, e.g. } \\
\text { daidzein, genistein } \\
\text { Coumarins, e.g. } \\
\text { coumestrol }^{3} \\
\text { Chalcones, e.g. } \\
\text { isoliquiritigenin }\end{array}$ & $\begin{array}{l}\text { Flavin, Riboflavin } \\
\text { Flavone, } 7 \text {-hydroxy } \\
\text { 5-methyl flavone }\end{array}$ \\
\hline$R$ melilori & $\begin{array}{l}\text { Flavones, e.g. } \\
\text { luteolin, apigenin }\end{array}$ & $\begin{array}{l}\text { Coumarins, e.g. } \\
\text { umbelliferone } \\
\text { Flavonols, e.g. } \\
\text { morn, quercitin }\end{array}$ \\
\hline
\end{tabular}

Data collated from: 1, Djordjevic et al. (1987). 2, Firmin et al. (1986). 3, Kosslak et al. (1987). 4, Kape et al. (1992). 5, Mellor and Rosendahl (1994). 6, Cunningham et al. (1991). 7, Peters and Long (1988).

Note that a compound (e.g. daidzein) acting as a nod-off in one system can act as a nod-on in another. Furthermore, it is highly likely that this list will be extended by future research.

* = Now known as Rhizobium leguminosarum biovar trifolii.

compounds. For example nodD1 of Rhizobium meliloti is activated by flavones like luteolin (Table 2), whereas the $R$ meliloti nodD2 is activated by betaines such as trigonelline and stachydrine (for an excellent recent overview see Demont et al., 1994). If the various nod-genes nod-off specificities vary it is unknown at present.

It may also be appropriate at this point to consider the speculation that some nod-ons may act as partial nodoffs in particular environments. One example of this may be the action of isoliquiritigenin and daidzein or genistein on the nod-genes of Bradyrhizobium japonicum. Isoliquiritigenin is a very efficient nod-on, inducing $B$. japonicum nod-genes at lower concentrations than daidzein does (Kape et al., 1992). Isoliquiritigenin, however, induces nod-genes to a lower extent than either daidzein or genistein do (Kape et al., 1992). Daidzein is a major component of soybean root exudate and may give rise to high nod-gene expression in bacteria in the outer rhizosphere (Kosslak et al., 1987). Thus it is of high importance to know if isoliquiritigenin can compete with or displace daidzein or genistein as inducer. If so, bacteria closer to the root may be induced by isoliquiritigenin and not daidzein, thus experiencing a reduction in nod-gene expression. The efficient nod-on will thus be acting functionally as a partial nod-off. This appears
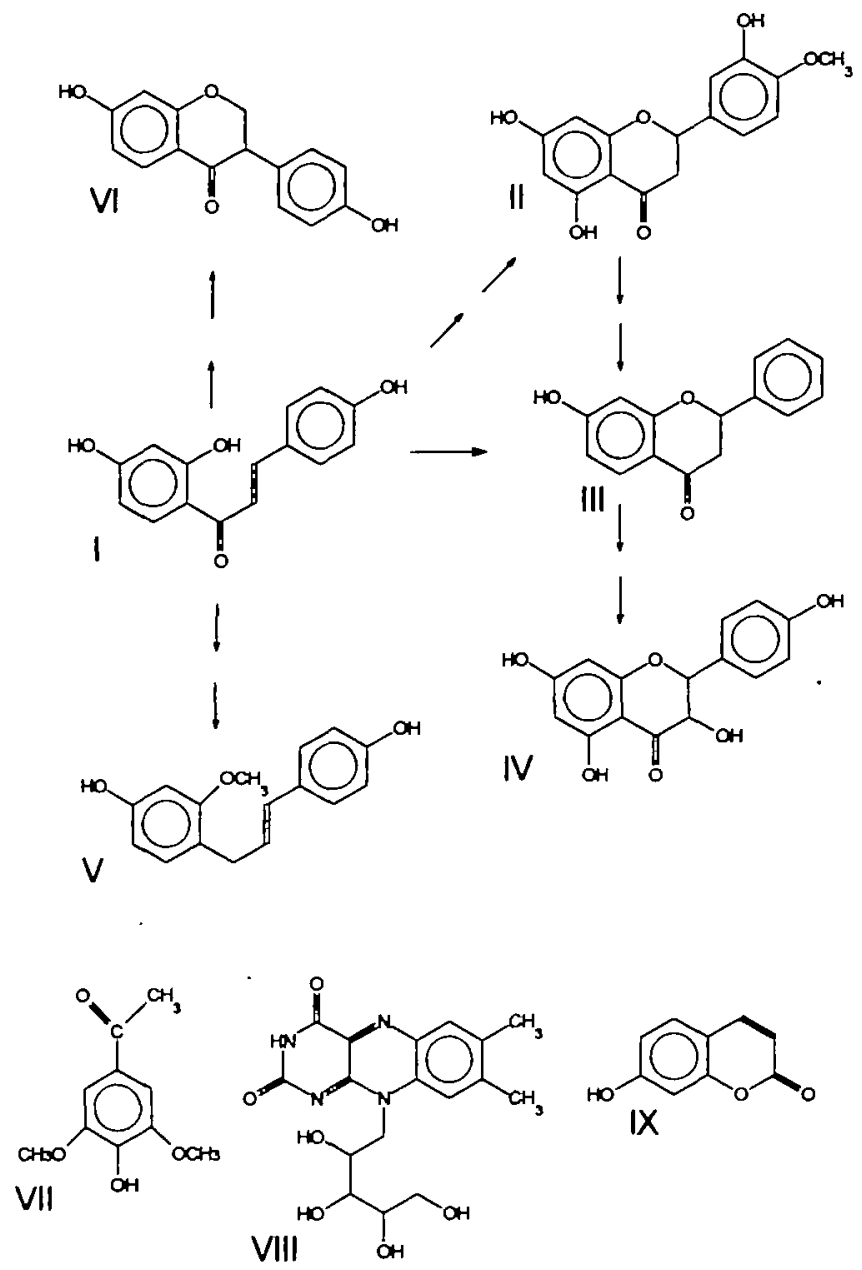

Fig. 4. Molecular formulae of selected nod-ons and nod-offs. I-VI: members of the polyisoprenyl family: I, chalcone, II, flavone, III, hesperitin, JV, kaempferol, V, isoliquiritigenin, VI, daidzein. Note that stimulation of this pathway can produce both nod-ons and nod-offs. VII-IX, non-related nod-offs: VII, acetosyringone, VIII, riboflavin, IX, ubiquinone.

likely, as indicated by the data of Hartwig et al. (1989) who obtained similar results after studying the effects of the weak nod-ons 4',7-dihydroxyflavone and $4^{\prime}, 7$-dihydroxyflavanone on the nod-gene induction in Rhizobium meliloti caused by the efficient nod-on luteolin.

Since nitrogen-fixing nodules are known to contain large quantities of putative nod-off(s) (Schlaman et al., 1991; Fehling et al., 1992) and that at least one nod-off is located mostly in the peribacteroid space (Fehling et al., 1992; Mellor and Rosendahl, 1994) then the bacteroidal nod-genes must be repressed (as indeed they mostly are, Schlaman et al., 1991), a factor possibly explaining the well-known lower infectivity of freshly-isolated bacteroids (first described by Hiltner and Störmer, 1903).

After root infection with bacteria, many thousands of infection threads are formed (Bieberdorf, 1938; Callaham and Torrey, 1981). Often many of these, sometimes the vast majority, are aborted and thus do not lead to nodule 
formation. It has been reported that single cells adjacent to, or in front of, infection threads exhibit characteristics of the 'hypersensitive response' (Vasse et al., 1993). This is in line with the speculation that Nod-factor production in these infection threads has not been sufficiently reduced and that, consequently, an elicitation and host response has taken place. Thus, in our hypothesis, we assume that the amount or availability of nod-off in the plant tissue is a limiting factor in nodulation. Basically, the ability of the plant to transport the amount of nod-off needed to repress Nod-factor production into the advancing infection thread can determine the number of nodules formed (this is discussed further in connection with supernodulating plant mutants in Section 9). In this respect, it is unfortunate that no data are available at present which correlate the root zones of infectibility (Turgeon and Bauer, 1982; Calvert et al., 1984) with the root zones containing clear zones of nod-on and nod-off activities (Djordjevic et al., 1987).

The ability of developing $\mathrm{Fix}^{+}$nodules to suppress further nodulation (Caetano-Anollés et al., 1991) can be explained by a similar mechanism. Nodules contain large amounts of nod-off(s) (Fehling et al., 1992) and must, therefore, be major sinks for such molecules. Thus nodules may simply reduce the amount of nod-off available to facilitate further infection, or, by perturbing the hormone balance (Jacobs and Rubery, 1988), restrict the translocation of nod-off(s) to the infected areas. Unfortunately, mechanisms involving the translocation of nod-offs within the plant have not been elucidated. Furthermore, this translocation model does not take signalling within the plant (Delves et al., 1986; Carroll and Mathews, 1990), nor the hormonal imbalances provoked by nodulation (Arora et al., 1959; Wang et al., 1982), into account. It is therefore open to further modification, but is, however, supported circumstantially by observations that ineffective (Fix ${ }^{-}$) nodules on soybean are often bad autoregulators (Bauer, 1981) and that they contain only low levels of the nod-off riboflavin (Fehling et al., 1992; see also Pankhurst et al., 1974). A simplified scheme presenting the postulated roles of nod-ons and nod-offs in regulating Nod-factor expression, and the interaction of Nod-factors with chitinases, is presented in Fig. 2.

\section{(8) Inhibition of nodulation by nitrate and light}

Light on roots is known to be an effective inhibitor of nodulation (Rudin, 1956), and thus complements the classical nodulation inhibitor, nitrate (Thornton, 1936; Tanner and Anderson, 1964; for review see Brewin, 1991). As part of the hypothesis presented here, we speculate that the presence of strong light, or significant concentrations of nitrate, reduces the amount of biologically active and available nod-off (e.g. riboflavin) in the root to the extent that the nod-genes of the invading bacteria can no longer be sufficiently repressed. This, combined with the stress-effects that both light and nitrate directly exert on root tissue (Wingender et al., 1989; Lee and LaRue, $1992 a, b)$ means that increased elicitation takes place and the growing infection threads are more likely to be aborted, resulting in reduced nodulation. We draw attention to the fact that both of these factors (light and nitrate) exert a direct destructive effect on the soybean nod-off riboflavin (the effects on other nod-offs are unknown at present, indeed, some root nodulators and all stem-nodulators like Sesbania rostrata and various Aeschynomene spp. nodulate well in the presence of light). Riboflavin is well known to be labile in the presence of blue light, but is stable under red light. Indeed it is blue, not red light, which inhibits nodulation (Lie, 1969). Furthermore, the nod-off activity in ethanolic extracts of soybean seedling roots can be destroyed under conditions known to inhibit nodulation. Figure 5 shows that soybean seedlings at a highly infectible stage in development contain large amounts of nod-off activity. This activity was significantly reduced, by $26 \%$ or $52 \%$, by pretreatment of the seedlings with either strong light or $10 \mathrm{mM} \mathrm{KNO}_{3}$, respectively (Fig. 5).

The inhibition of nodulation by light and by nitrate are, however, not exactly similar in all respects. Lee and LaRue (1992a) have reported that the inhibition of nodulation by light and by nitrate exhibit certain differences; the blocking of infection thread formation being at an earlier stage using nitrate (see also Streeter, 1988). This is in agreement with the hypothesis presented here. In addition to the almost hormone-like effects of nitrate on plants, the inclusion of nitrate with roots results in an increased evolution of endogenous ethylene (Lee and

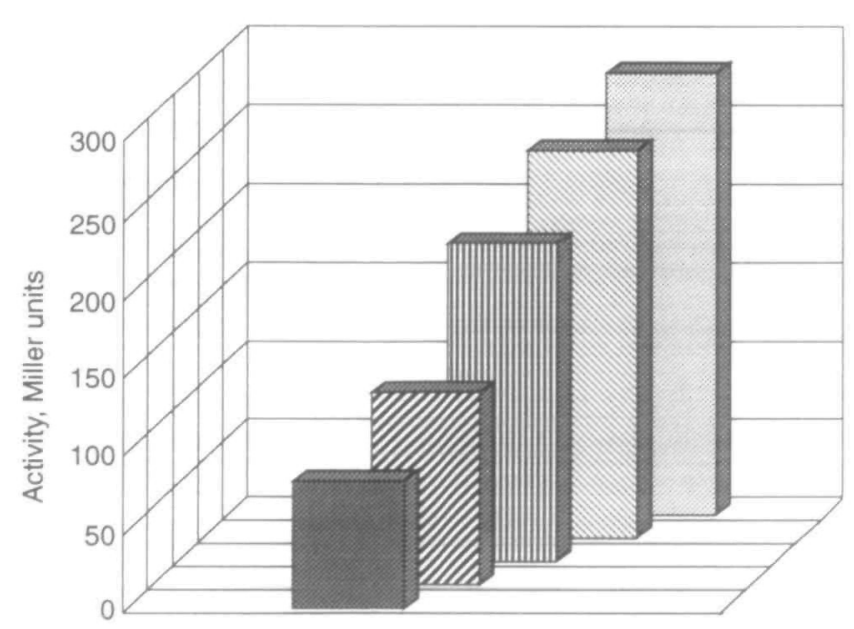

Fig. 5. The endogenous activity (front bar) of a Bradyrhizobium japonicum nodC-lacZ fusion (pRJ458, Gottfert et al., 1992) or exposed to $5 \mu \mathrm{M}$ daidzein (rearmost bar) or ethanolic extracts from soybean roots. Extracts were prepared from 7-d-old seedlings grown either in the dark immersed in water (second bar from front), or in the dark in $10 \mathrm{mM} \mathrm{KNO}_{3}$ solution (third bar), or in water under a strong white light (fourth bar). Details are given in Mellor and Rosendahl (1994). 
LaRue, $1992 a, b$ ), indicating that the infectible tissue, which, in soybean, already contains significant levels of the phytoalexin glyceollin (Schmidt et al., 1992) is, therefore, probably more highly sensitive to elicitation (see Boller, 1988) than non-nitrate-treated tissue. In addition, nitrate results in lowered levels of root lectins (Dazzo and Brill, 1978). In Section 5, we speculated that lectins may be responsible for masking eliciting Nod-factors. Thus, when the roots are exposed to nitrate, homologous Nod-factors would be expected to elicit more root chitinase earlier. This contention is supported by the observation that, in some cases, root hair curling can be significantly reduced in the presence of nitrate (Thornton, 1936; Munns, 1968), i.e. that the higher chitinase levels have hydrolysed large amounts of Nod-factor, resulting in a reduced biological (root hair curling) activity. In addition to this, legume chitinases, which also possess significant lysozyme activity (Boller, 1988; Düring, 1993) may directly attack bacterial cell walls. The few bacteria which survive these adverse conditions and start infection thread formation are confronted by a lack of nod-off activity (Fig. 5) and thus are unable to reduce the rate of Nod-factor production sufficiently to escape the heightened sensitivity of the host plant defence responses. Thus the inhibition of nodulation brought about by nitrate occurs at an earlier stage in the infection process than the inhibition brought about by light.

Plant mutants have been described where the inhibition of nodulation by nitrate is no longer effective (nitrate tolerant symbiosis, nts, mutants, see Section 9). Unfortunately, mutants have not yet been described where nodulation is insensitive to the effects of light. Such mutants would be relatively easy to screen for (i.e. by growth on $\mathrm{N}$-poor medium after illumination and infection, and assaying for a green plant phenotype).

\section{(9) Plant symbiotic mutants, some suggestions}

Nodulation variants have been known for some 40 years (Williams and Lynch, 1954), and progress at the molecular level has accelerated dramatically since the original success of Gresshoff's group in isolating supernodulating and nitrate tolerant symbiosis (Nts) (Carroll et al., 1985), as well as non-nodulating (Carroll et al., 1986) soybean lines, after chemical mutagenesis.

Non-nodulating soybean mutants (both $r j_{1}$ and $r j_{6}$ loci) are characterized by their lack of root hair curling (Mathews et al., 1987) and also ( $r j_{1}$ locus) very low incidence of sub-epidermal cell divisions (Mathews et al., 1989) after exposure to Bradyrhizobium. Thus the plants react as if they had not perceived Nod-factors. They may therefore lack elicitor or Nod-factor receptors. In the light of the hypothesis presented here, however, this could also be explained as being due either to the plant overproducing nod-offs or being very elicitable and producing large amounts of Nod-factor hydrolysing chitinase. The first alternative can be ruled out. Co-culture experiments show that non-nodulators cultured in close proximity to either wild-type or supernodulators produce no appreciable change in nodulation on the second plant (Mathews et al., 1987). The second alternative has received circumstancial support from Gollotte et al. (1993) who took a non-nodulating $\left(\mathrm{Nod}^{-}\right.$) pea mutant which was also unable to enter into symbiosis with vesicular-arbuscular mycorrhizas (i.e. was also $\mathrm{Myc}^{-}$) and found that the $\mathrm{Nod}^{-} \mathrm{Myc}^{-}$mutant plants (but not wild-type plants) produced a significant defence response when challenged with Glomus mosseae. It would thus be interesting to see if non-nodulating mutant plants constitutively express high levels of chitinase or if they are highly elicitable, for example, if they produce a large ethylene peak upon infection.

It should be noted here that two of the non-nodulating mutants (nod139 and nod49), postulated here to have an overactive defence system as regards chitinase, are able to enter into normal symbioses with vesicular-arbuscular mycorrhizas, e.g. Glomus mosseae (i.e. they are $\mathrm{Myc}^{+}$, Wyss et al., 1990, as are many other Nod $^{-}$mutants). This is, however, not contradictory in any way, since Vierheilig et al. (1993) have shown that Glomus mosseae can successfully colonize transgenic roots constitutively expressing high levels of chitinase. Thus we suspect chitinase to be an important element in the non-nodulation phenotype, but other defence reactions (possibly independent of chitinase) to play the major role in the nonmycorrhization phenotype.

In contrast to the non-nodulators, the supernodulating soybean mutant nts382 forms infection threads after inoculation to the same degree as wild-type plants do. Unlike the wild-type, however, a very large proportion of these infection threads develop into nodules (Mathews et al., 1989). In accordance with the hypothesis presented here, it can be speculated that supernodulators are either lacking in some element of their defence mechanisms or are especially able to translocate large amounts of nodoffs to the growing infection threads. The former can be tested by assaying for changes in defence-related gene expression, especially the relevant chitinases (see Section 2) upon challenge with symbionts.

The site of nod-off synthesis in young, pre-inoculation, seedlings is unknown, but may be the shoot or cotyledons since, in the soybean system, exposing the above-ground parts of the plant to strong light (known to destroy riboflavin, one of the soybean nod-offs) prior to infection seriously $(50 \%)$ reduces nodulation (Malik et al., 1984). It is thus tempting to speculate that the translocatable shoot factor causing supernodulation in nts 382 is a nodoff, perhaps riboflavin. Unfortunately, mechanisms of nod-off transport in plants have not yet been studied. It 
is also presently unknown whether a nod-off like riboflavin can substitute for the shoot factor.

One test of the above hypothesis has been provided by chimeric split-root system experiments, where nonnodulating roots were grafted on to a wild-type (or supernodulating) plant, which also retained some roots (Caetano-Anollés and Gresshoff, 1990). In a split-root assay the side with the non-nodulating roots was inoculated slightly before the wild-type (or supernodulating) side. According to the hypothesis presented now, this could be explained as follows; the first inoculation resulted in the.signal postulated by Carroll and Mathews (1990) to the shoot and resulting in the mobilization of nod-off in the shoot (Carroll and Mathews, 1990). After translocation to the root, most of the nod-off would be re-routed to the wild-type side (the non-nodulating side not being a sink, since the high chitinase levels would have destroyed the Nod-factor and most of the few infection threads). Thus inoculation on the wild-type side of the chimeric split-root system would be expected to result in increased nodulation (a phenotype otherwise unknown) since these roots would be receiving a nod-off supply more similar to that in supernodulating roots. Indeed, Caetano-Anollés and Gresshoff (1990) reported that nod139 roots had a positive effect on the nodulation of the wild type, and especially on the nodulation of nts 382 . This interpretation could be double-checked by laying the chimeric root system, at appropriate times during the experiment, on lawns of bacteria carrying the relevant nod-lac $Z$ construct.

\section{(10) The role of the peribacteroid membrane}

Werner et al. (1985) first reported that levels of phytoalexin are higher in nodules where the peribacteroid membrane is lacking (confirmed by Grosskopf et al., 1993). This has traditionally been explained as follows; where there is no peribacteroid membrane, the bacterial surface is revealed to the plant and can be recognized as non-self, i.e. bacterial surface elicitors are in direct contact with the plant cytoplasm. In the light of this hypothesis, however, a parallel explanation becomes possible; an intact symbiosome is needed as target organelle for riboflavin or other nod-offs. Without an intact symbiosome (an intact peribacteroid membrane), the concentration of nod-off around the bacteroid cannot reach the levels needed to repress Nod-factor synthesis and thus elicitor production proceeds unchecked. Thus the $\mathrm{Fix}^{-}$nodules reported by Werner et al. (1985) and Grosskopf et al. (1993) showing clear signs of extra elicitation, would also be expected to contain high levels of Nod-factor. Indeed, bacteroids which express nodD at wild-type levels inhabit Fix - nodules (Schlaman et al., 1991, see Section 7), but it is currently unknown whether plant defence reactions are induced in these nodules. This could be tested using immunocytological techniques and/or in situ hybridization (Yang et al., 1992).

It would also be highly interesting to see whether peribacteroid membranes contain receptors for Nodfactors or other elicitors (see below, Section 11). Peribacteroid membrane-located activities transporting nod-ons and/or nod-offs (Table 2; Fig. 4) into the peribacteroid space may also finally be useful in defining marker enzymes for this membrane, for use in subcellular fractionation studies.

\section{(11) The peribacteroid space and nodule senescence}

In soybean, nodule senescence starts around flowering (Craft-Bradner et al., 1984) and thus the decline in nitrogen fixation precedes pod set and, therefore, there is little or no biologically-fixed nitrogen available for seed reserves during pod-filling, a situation exasperating for agronomists. Senescence has been proven to be a predetermined developmental sequence by Mohammadi and Karr (1993) who nodulated multifoliate (flowering) and trifoliate (non-flowering) soybean cuttings and found that nodules on plants derived from both types of cutting had similar life times. Mature nodules are similar to mildly elicited tissue (e.g. soybean treated with Phytophthora megasperma elicitor, see Graham and Graham, 1991) in as much as they exhibit very high concentrations of daidzin, the glycosylated form of the glyceollin precursor, daidzein (Meyer and Mellor, 1993) and raised, but not extreme (Table 1) levels of phytoalexin (Werner et al., 1985). The onset of senescence is marked by a rise in the nodule glyceollin content (Karr et al., 1992).

We propose the following explanation for the above results. In mature soybean nodules, the peribacteroid space contains both the nod-on daidzin (Meyer and Mellor, 1993) and the nod-off riboflavin (Fehling et al., 1992; Fig. 6A). The daidzin may be needed to assist in the export of bacterial proteins (Krishnan and Pueppke, 1993; Katinakis et al., 1988) essential for plant symbiotic gene expression (Welters et al., 1993). At a mature stage in nodule development, peribacteroid space preparations exhibit a clear nod-off activity (Mellor and Rosendahl, 1994; Fig. 6B). Thus in mature nodules, Nod-factor production is held within tolerable limits. During development, however, the riboflavin content of the peribacteroid space falls, and the peribacteroid space loses its ability to down-modify nod-gene expression (Fehling et al., 1992; Fig. 6A, B), thus Nod-factor synthesis must rise. We propose that the additional elicitation associated with this increased Nod-factor production causes a rise in cellular glyceollin levels, as demonstrated by Savoure et al. (1994). The bacteroids are immune to the effects of glyceollin (Parniske et al., 1981), but the host cell mitochondria (Boydston et al., 1983) and membranes (Weinstein et al., 1981) can be expected to be affected, resulting in a 

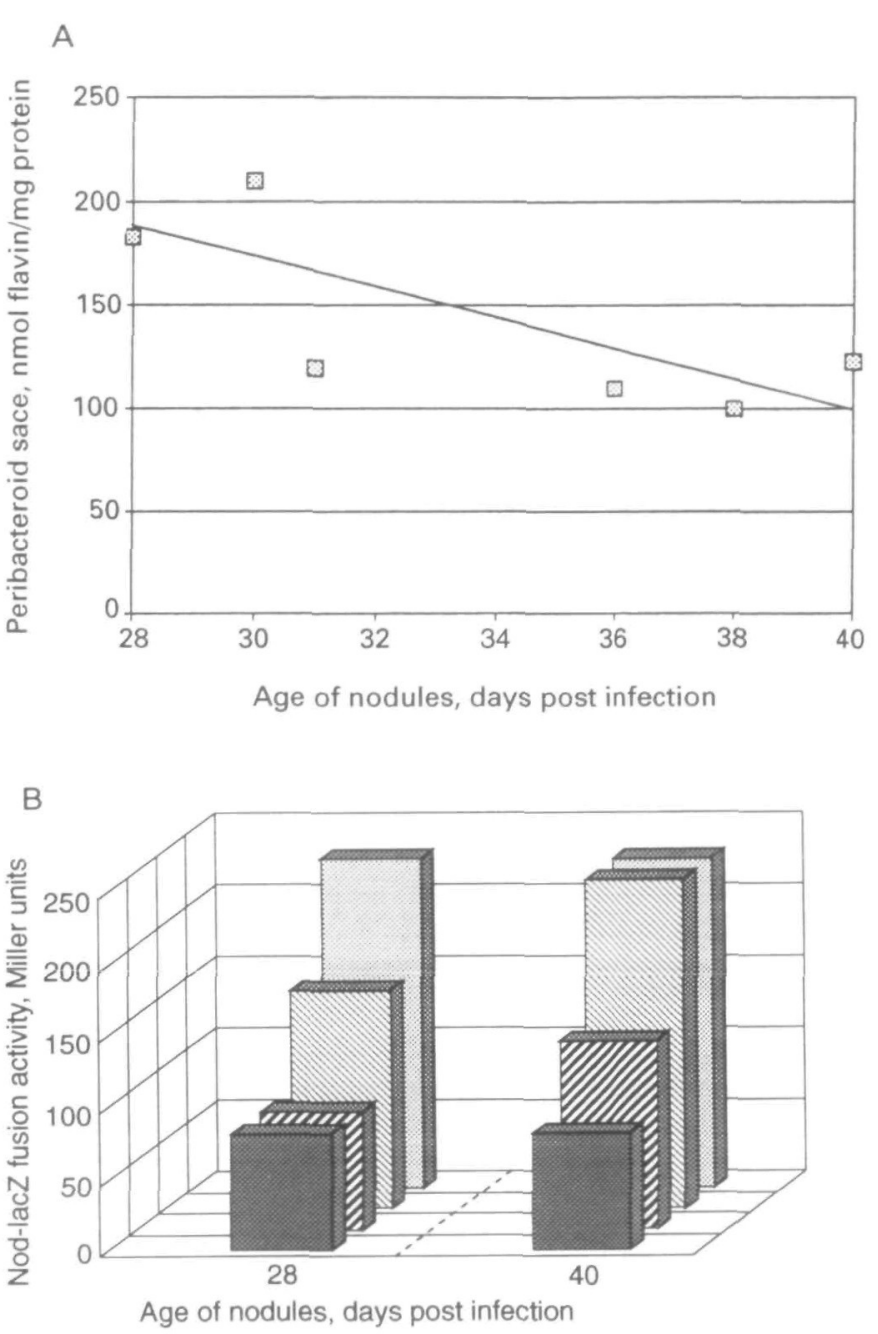

Fig. 6. (A) Riboflavin content of the peribacteroid space from mature and ageing soyhean nodules (redrawn from Fehling at al. 19921. indicating ( $B$ ) the nod-off nod-on activity of the peribacteroid space on Brudrrhizohium japhomicum. of such preparations at nodule mat urity 28 d.p.i.) or start of senescence (40) d.p.i.). The bars represent. from front to back. the background level of a med lar $Z$ fusion construct, the construct treated with 60 $\mu \mathrm{g}$ PBS protein Inod-on atis ity): the construct treated with $5 \mu \mathrm{M}$ daidzein and 6) $\mu$ PBS protein Inol-off atcisitw: the construct treated with $5, \mathrm{M}$ ditidzein only lfull induction isec Mellor ind Rosendahl. 1994,

breakdown of the plants compartmentation and metabolism.

If lectin(s) are involved in masking Nod-factors lsee Section 51 . then lectin molecules may also be present in the peribacteroid space (VandenBosch $t$ t al.. 1994).

Interestingly. elevated levels of expression of plant chalcone synthase (CHS) genes have recently been reported in the meristem of both determinate (Estabrook and Sengupta-Gopalan. 1991) and indeterminate nodules (Yang 't al. 1992). CHS maty well be involved in providing flatonoids to act as natural anti-ituxins (Jacobs and Rubery. 1988 , needed for the development of nodule structure (Long and Cooper. 1988: Hirsch 't al. 1989). as well as defence reactoon intermediates in certatm mon- symbiotic or senescent nodules. Paradoxically. low CHS expression may also be needed to provide flavonoid nodoffs (Table 2: Fig. 4), so that elicitation is kept within allowable limits and defence reactions are delayed until the appropriate stage. This interpretation is supported by the findings of Estabrook and Sengupta-Gopalan (1991) that, in nodules, symbiosis-specific CHS genes are a subset of all CHS genes and that they are regulated independently of stress-induced or pathogen interaction- controlled genes. Indeed. Wingender et al. (1989) also reported that CHS expression in nodules consists of two waves. an early wave (here postulated as providing nod-offs and or nod-ons acting as functional nod-offs. see Section 7) and a second wave, occurring slightly before senescence (here interpreted as providing phytoalexin), but it is not known if this second wave of expression is related to the symbiosis-specific CHS genes or others. Furthermore. Maxwell et al. (1993) reported that isoflavonoid biosynthesis is higher than, and uncoupled from, nod-on synthesis in Medicago nodules, implying that either nod-offs (or, at a later stage. phytoalexins) are being produced. An additional level of complexity is added by the perturbation of hormone levels in nodules, which can be in response to, or even mediated by, the microsymbiont (Sturtevant and Taller, 1989), and which can also affect the expression of plant defence response genes (Robinette and Matthysse. 1990: Dominov et al., 1992).

Nodule chitinase levels do rise slightly during senescence (Staehelin et al., 1992a), but not upon treatment of nodulated plants with either nitrate or darkness (Fig. 7). This implies that the premature, nitrate- (or darkness-) induced senescence of nodules (Brewin, 1991: Paau and Cowles. 1981) cannot be explained by the plant defence model presented here. and has a different physiological basis from the nitrate- (or light-) induced inhibition of nodulation. This is in agreement with earlier studies on nitrate-treated nodules (Streeter. 1986: Heckmann and Drevon, 1988). which have explained induced senescence purely in terms of carbon partitioning.

Thus in order to develop plants with nodules capable of fixing nitrogen for longer periods. including. where appropriate. through flowering and into pod filling. either plants must be bred which sequester more nod-off into the peribacteroid space late in the symbiosis. or the apparent paradox of infecting nodules with bacteria having no nod-genes must be solved. Further strategies in this area could be constructed after studies on nonsenescing nodules. e.g. Phaseolus vulgaris, or even the perennial nodules of Sophora. have been completed.

\section{Future perspectives}

Much has been achieved in recent gears in understanding the nature of nodulation. the regulatory phovological 
A
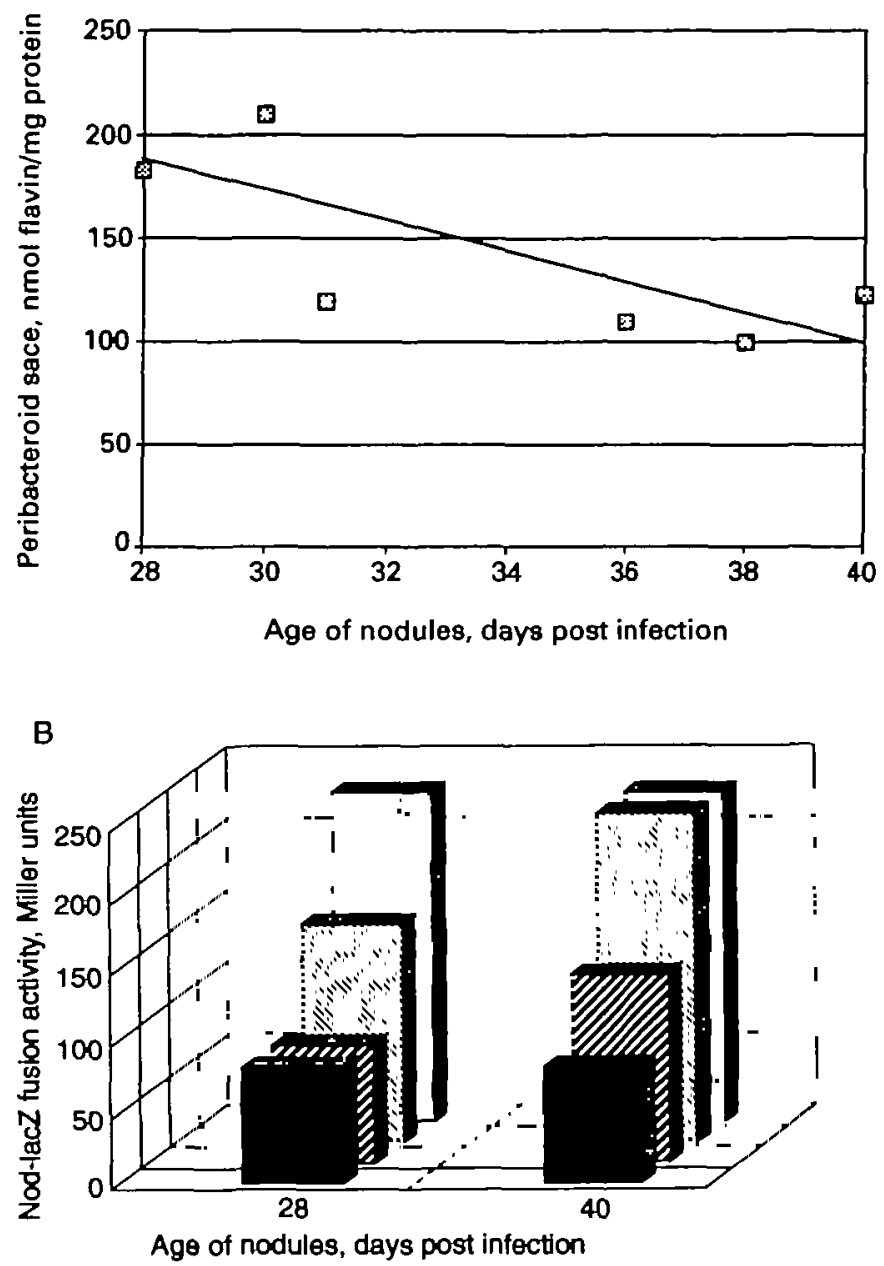

Fig. 6. (A) Riboflavin content of the peribacteroid space from mature and ageing soybean nodules (redrawn from Fehling et al., 1992), indicating (B) the nod-off/nod-on activity of the peribacteroid space on Bradyrhizobium japonicum, of such preparations at nodule maturity ( 28 d.p.i.) or start of senescence ( 40 d.p.i.). The bars represent, from front to back, the background level of a nod-lac $Z$ fusion construct; the construct treated with $60 \mu \mathrm{g}$ PBS protein (nod-on activity); the construct treated with $5 \mu \mathrm{M}$ daldzein and $60 \mu \mathrm{g}$ PBS protein (nod-off activity); the construct treated with $5 \mu \mathrm{M}$ daidzein only (full induction) (see Mellor and Rosendahl, 1994).

breakdown of the plants compartmentation and metabolism.

If lectin(s) are involved in masking Nod-factors (see Section 5), then lectin molecules may also be present in the peribacteroid space (VandenBosch et al., 1994).

Interestingly, elevated levels of expression of plant chalcone synthase (CHS) genes have recently been reported in the meristem of both determinate (Estabrook and Sengupta-Gopalan, 1991) and indeterminate nodules (Yang et al., 1992). CHS may well be involved in providing flavonoids to act as natural anti-auxins (Jacobs and Rubery, 1988) needed for the development of nodule structure (Long and Cooper, 1988; Hirsch et al., 1989), as well as defence reaction intermediates in certain non- symbiotic or senescent nodules. Paradoxically, low CHS expression may also be needed to provide flavonoid nodoffs (Table 2; Fig. 4), so that elicitation is kept within allowable limits and defence reactions are delayed until the appropriate stage. This interpretation is supported by the findings of Estabrook and Sengupta-Gopalan (1991) that, in nodules, symbiosis-specific CHS genes are a subset of all CHS genes and that they are regulated independently of stress-induced or pathogen interaction- controlled genes. Indeed, Wingender et al. (1989) also reported that CHS expression in nodules consists of two waves, an early wave (here postulated as providing nod-offs and/or nod-ons acting as functional nod-offs, see Section 7) and a second wave, occurring slightly before senescence (here interpreted as providing phytoalexin), but it is not known if this second wave of expression is related to the symbiosis-specific CHS genes or others. Furthermore, Maxwell et al. (1993) reported that isoflavonoid biosynthesis is higher than, and uncoupled from, nod-on synthesis in Medicago nodules, implying that either nod-offs (or, at a later stage, phytoalexins) are being produced. An additional level of complexity is added by the perturbation of hormone levels in nodules, which can be in response to, or even mediated by, the microsymbiont (Sturtevant and Taller, 1989), and which can also affect the expression of plant defence response genes (Robinette and Matthysse, 1990; Dominov et al., 1992).

Nodule chitinase levels do rise slightly during senescence (Staehelin et al., 1992a), but not upon treatment of nodulated plants with either nitrate or darkness (Fig. 7). This implies that the premature, nitrate- (or darkness-) induced senescence of nodules (Brewin, 1991; Paau and Cowles, 1981) cannot be explained by the plant defence model presented here, and has a different physiological basis from the nitrate- (or light-) induced inhibition of nodulation. This is in agreement with earlier studies on nitrate-treated nodules (Streeter, 1986; Heckmann and Drevon, 1988), which have explained induced senescence purely in terms of carbon partitioning.

Thus in order to develop plants with nodules capable of fixing nitrogen for longer periods, including, where appropriate, through flowering and into pod filling, either plants must be bred which sequester more nod-off into the peribacteroid space late in the symbiosis, or the apparent paradox of infecting nodules with bacteria having no nod-genes must be solved. Further strategies in this area could be constructed after studies on nonsenescing nodules, e.g. Phaseolus vulgaris, or even the perennial nodules of Sophora, have been completed.

\section{Future perspectives}

Much has been achieved in recent years in understanding the nature of nodulation, the regulatory physiological 

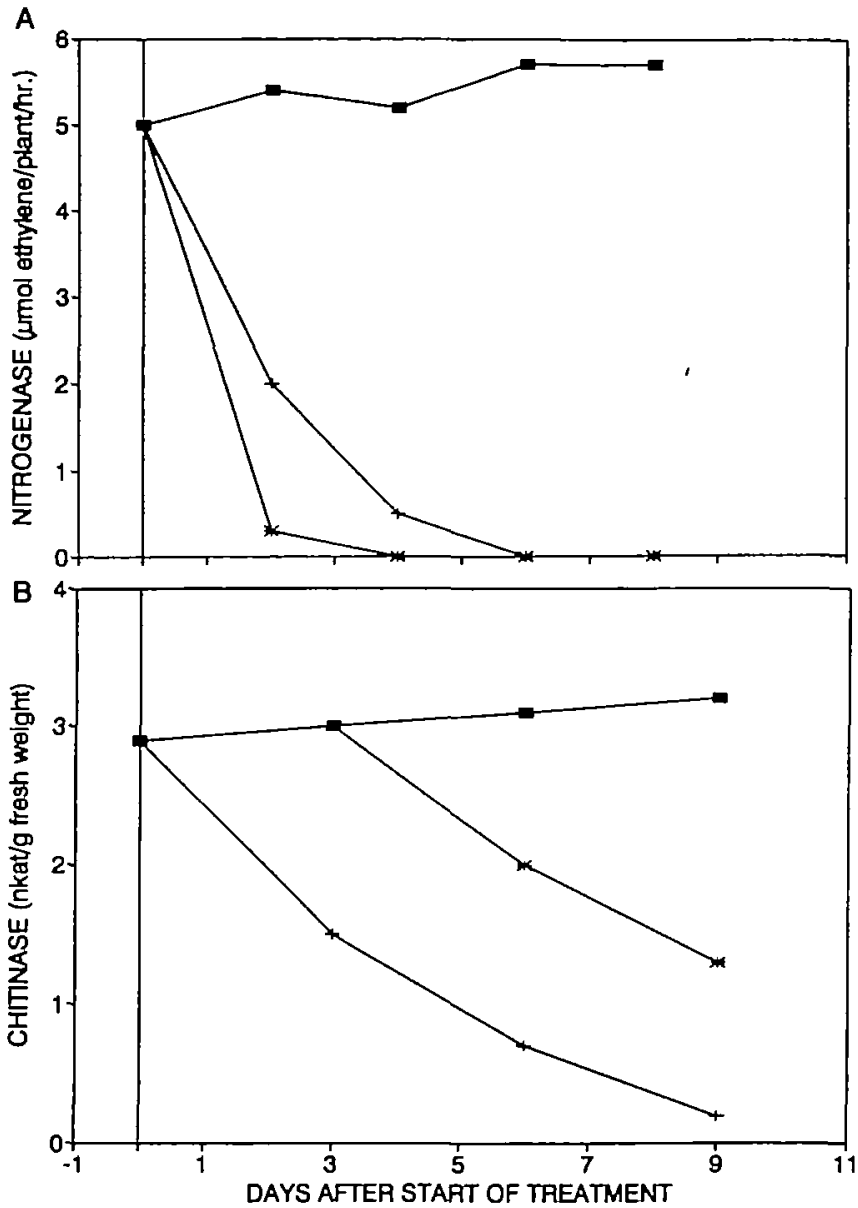

Fig. 7. (A) Nitrogenase activity (measured as acetylene reduction for $15 \mathrm{~min}$ in closed system) and (B) chitinase activity, in soybean root nodules of control plants with $1 \mathrm{mM}$ nitrate ( $\square)$, or in plants exposed to continual darkness $\left(^{*}\right)$ or inhibitory $(10 \mathrm{mM})$ levels of nitrate $(+)$. Redrawn from Vignutelli (1991).

processes, and the nature of the bacterial signals which trigger nodulation. Little is understood of the mechanisms by which the signals work. Current work primarily concerns nodulin gene expression and nodule differentiation. We have presented an hypothesis in which we propose that the regulation of nodulation is dependent on a balance involving the elicitation of defence responses in plants by Nod-factors, the synthesis of which is stimulated by nod-ons and suppressed by nod-offs (or finely tuned by nod-ons acting functionally as nod-offs). The identification of these nod-active chemicals, their mode of action and interplay, are obvious areas for future research. The biosynthetic pathways for nod-ons and nod-offs deserve more attention, as well as their distribution and transport within the plant. This may eventually facilitate the development of plants mutated in their ability to produce nod-ons (nod-on ${ }^{-}=\mathrm{Non}^{-}$), or nod-offs (nodoff $^{-}=\mathrm{Nof}^{-}$). The development of extensive molecular (RFLP, DAF, microsatellites, and RAPD markers) and contig libraries will facilitate map-based cloning of the genes in question. Alternatively, insertional mutagenesis (for example with T-DNA into model legumes) may produce symbiotic mutants, which after segregation and linkage analysis may be used to isolate the causative DNA sequences flanking the T-DNA insert.

A clear priority for the future is the identification of receptors for Nod-factors. Analogues and antagonists will be invaluable tools for identifying receptors, whereas competitive inhibitors, Nod-factor mimics and hybrid Nod-factors will be useful for studying their function. Antisera against Nod-factors should also be useful for inhibition studies in addition to immunohistochemical investigations.

Given that the major breakthroughs in understanding the bacterial side of nodulation originated in molecular genetic studies, the results obtained from plant studies are remarkable, primarily by their absence. In this respect, the development of model legume genetic systems e.g. Lotus japonicus (Stougaard, 1993) and Medicago truncatula (Thomas et al., 1992) could be an important step forward. A number of metabolic mutations would be of interest. The challenge will come in identifying simple and effective screening assays. Of course $\mathrm{Nod}^{-}, \mathrm{Fix}^{-}$and Nts mutations exist already and have been discussed above. Mutations involving, for example, the HR effect (Werner et al., 1985) could be identified using ELISA assays against phytoalexins (Schmidt et al., 1992). Mutants non-responsive to Nod-factors would not exhibit a root-hair-curling phenotype. These would be useful for identifying components of the signal transduction pathway leading to the development of the nodule. Parallel studies with, for example, peanut systems, where entry does not involve curled root hairs (crack entry), may provide further clues.

An alternative to random mutagenesis for studying the effects of particular gene products is through using transgenic plants. Anti-sense constructs using known genes can be used to suppress the translatability of specific mRNAs, and over-expression can be used to enhance the levels of mRNA and, consequently, the encoded protein. These methods have the advantage over shotgun mutation studies in that specific genes can be targeted without the need to determine what the affected gene is afterwards. In particular, transgenic studies offer the opportunity to determine the role of specific root and nodule defence genes, e.g. chitinases and enzymes of phenylpropanoid biosynthesis, in the regulation of plant response to microbial challenge. However, results obtained in analogous plant-pathogen interaction systems have not been encouraging. Constructs either suppressing (e.g. de Carvalho et al., 1992), or over-expressing (Neuhaus et al., 1991) specific gene sequences have had no measurable effect on pathogen infection. Thus it may be necessary to make plants altered in the expression of several different genes or identify regulatory factors and/or receptors. 
Our model rests on proven characteristics of the plant defence response and provides a simple explanation for all aspects of nodulation. We have presented this hypothesis purely in order to stimulate experimentation (and have therefore included over 40 suggestions for further experiments, 30 of which are of a relatively simple nature and are quick and easy to perform). Successful researchers need not, however, feel obliged to cite this hypothesis, as we do not wish to register a priority claim.

\section{Acknowledgements}

Financial support was provided by the EC biotechnology programme (B/BIOT/923118). We thank Nick Brewin, Peter Gresshoff, Kjeld Engvild, Morten Heide, and Lone Rossen for their invaluable comments on the pre-publication manuscript.

\section{References}

Arora N, Skoog F, Allen ON. 1959. Kinetin-induced pseudonodules on tobacco roots. American Journal of Botany 46, 610-13.

Basse CW, Fath A, Boller T. 1993. High affinity bonding of a glycopeptide elicitor to tomato cells and microsomal membranes and displacement by specific glycan suppressors. Journal of Biological Chemistry 268, 14724-31.

Bauer WD. 1981. The infection of legumes by rhizobia. Annual Review of Plant Physiology 32, 407-49.

Bent AF, Innes RW, Ecker JR, Staskawicz BJ. 1992. Disease development in ethylene-insensitive Arabidopsis thaliana infected with virulent and avirulent Pseudomonas and Xanthomonas pathogens. Molecular Plant Microbe Interactions 5, 372-8.

Bhuvaneswari TV, Bauer WD. 1978. Role of lectins in plantmicroorganism interactions. III. Binding of soybean lectin to root cultured rhizobia. Plant Physiology 62, 71-4.

Bhuvaneswari TV, Turgeon BG, Bauer WD. 1980. Early events in the infection of soybean (Glycine max L. Merr) by Rhizobium japonicum. I. Localization of infectible root cells. Plant Physiology 66, 1027-31.

Bieberdorf FW. 1938. The cytology and histology of the root nodules of some Leguminosae. Journal of the American Society of Agronomy 30, 375-89.

Boller T. 1988. Ethylene and the regulation of antifungal hydrolases in plants. In: Miflin BJ, ed. Oxford surveys of plant molecular and cell biology, Vol. 5. Oxford University Press, 145-74.

Borthakur D, Barker RF, Latchford JW, Rossen L, Johnston AWB. 1988. Analysis of pss genes of Rhizobium leguminosarum required for exopolysaccharide synthesis with psi and other nodulation genes. Molecular and General Genetics 312, 155-62.

Boydston R, Paxton JD, Koeppe DE. 1983. Glyceollin: a sitespecific inhibitor of electron transport in isolated soybean mitochondria. Plant Physiology 72, 151-5.

Brewin NJ. 1991. Development of the legume root nodule. Annual Review of Cell Biology 7, 191-226.

Caetano-Anolles G, Gresshoff PM. 1990. Early induction of feedback regulatory responses governing nodulation in soybean. Plant Science 71, 69-81.

Caetano-Anollés G, Gresshoff PM. 1991. Plant genetic control of nodulation. Annual Review of Microbiology 45, 345-82.

Caetano-Anollés G, Paparozzi ET, Gresshoff PM. 1991. Mature nodules and root tips control nodulation in soybean. Journal of Plant Physiology 137, 389-96.

Callaham DA, Torrey JG. 1981. The structural basis for infection of root hairs of Trifolium repens by Rhizobium. Canadian Journal of Botany 59, 1647-64.

Calvert HE, Pence MK, Pierce M, Malik NSA, Bauer WD. 1984. Anatomical analysis of the development and distribution of Rhizobium infections in soybean roots. Canadian Journal of Botany 62, 2375-84.

Carroll B.J, Mathews A. 1990. Nitrate inhibition of nodulation in legumes. In: Gresshoff PM, ed. Molecular biology of symbiotic nitrogen fixation. Florida: CRC Press, 159-80.

Carroll BJ, McNeil DL, Gresshoff PM. 1985. A supernodulation and nitrate tolerant symbiotic (nts) soybean mutant. Plant Physiology 78, 34-40.

Carroll BJ, McNeil DL, Gresshoff PM. 1986. Mutagenesis of soybean (Glycine max L. Merr.) and the isolation of nonnodulation mutants. Plant Science 47, 109-14.

Collinge DB, Gregersen PL, Thordal-Christensen H. 1994. The induction of gene expression in response to pathogenic microbes. In: Basra AS, ed. Mechanisms of plant growth and improved productivity: modern approaches and perspectives. New York: Marcel Dekker, 391-433.

Collinge DB, Kragh KM, Mikkeken JD, Nielsen KK, Rasmussen U, Vad K. 1993. Plant chitinases. The Plant Journal 3, 31-40.

Collinge DB, Slusarenko AJ. 1987. Plant gene expression in response to pathogens. Plant Molecular Biology 9, 389-410.

Craft-Bradner SJ, Below FE, Harper JE, Hageman RH. 1984. Effect of pod removal on metabolism and senescence of nodulating and non-nodulating soybean isolines. I. Enzymes and chlorophyll. Plant Physiology 75, 318-22.

Cunningham S, Kollmeyer WD, Stacey G. 1991. Chemical control of interstrain competition for soybean nodulation by Bradyrhizobium japonicum. Applied Environmental Microbiology 57, 1886-92.

Dazzo FB, Brill WJ. 1978. Regulation by fixed nitrogen of host-symbiont recognition in the Rhizobium-clover symbiosis. Plant Physiology 62, 18-21.

de Carvalho F, Gheysen G, Kushnir S, Van Montagu M, Inze D, Castresana C. 1992. Suppression of beta 1,3-glucanase transgene expression in homozygous plants. EMBO Journal 11, 2595-602.

de Faria SM, Sutherland JM, Sprent JM. 1986. A new type of infected cell in root nodules of Andira spp (Leguminosae). Plant Science 45, 143-7.

De Jong AJ, Cordewener $\mathbf{J}$, LoSchiavo $\mathbf{T}$, Terzi $\mathbf{M}$ Vandekerckhove J, Van Kammen A, De Vries SC. 1992. A carrot somatic embryo mutant is rescued by chitinase. Plant Cell 4, 425-33.

Delves AC, Mathews A, Day DA, Carter AS, Carroll BJ, Gresshoff PM. 1986. Regulation of the soybean-Rhizobium nodule symbiosis by root and shoot factors. Plant Physiology 82, 588-90.

Demont N, Ardourel M, Maillet F, Prome D, Ferro M, Prome JC, Denarie J. 1994. The Rhizobium meliloti regulatory nodD3 and syrM genes control the synthesis of a particular class of nodulation factors $N$-acetylated by (w-1)hydroxylated fatty acids. EMBO Journal 13, 2139-49.

Diaz CL, Melchers LS, Hooykras PJJ, Lugtenberg BJ., Kijne JW. 1989. Root lectin as a determinant of host-plant specificity in the Rhizobium-legume symbiosis. Nature 338 , 579-81.

Dixon RA. 1986. The phytoalexin response: elicitation, signalling and control of host gene expression. Biological Review's 62, 239-91. 
Djordjevic MA, Redmond JW, Batley M, Rolfe BG. 1987. Clovers secrete specific phenolic compounds which either stimulate or repress nod-gene expression in Rhizobium trifolii. EMBO Journal 6, 1173-9.

Dominov JA, Stenzler L, Lee S, Schwarz JJ, Leisner S. 1992. Cytokinins and auxins control the expression of a gene in Nicotiana plumbaginifolia cells by feedback regulation. Plant Cell 4, 451-61.

Dowling DN, Stanley J, Broughton WJ. 1988. Competitive nodulation blocking ( $\mathrm{Cnb}$ ) is determined by nod-genes in Rhizobium leguminosarum. In: Bothe $\mathrm{H}$, de Bruijn $\mathrm{FJ}$, Newton WE, eds. Nitrogen fixation: hundred years after. Stuttgart: Gustav Fischer, 443-8.

Düring K. 1993. Can lysozymes mediate antibacterial resistance in plants? Plant Molecular Biology 23, 209-14.

Ebel J, Cosio EG. 1994. Elicitors of plant defence responses. International Review of Cytology 148, (in press).

Estabrook EM, Sengupta-Gopalan C. 1991. Differential expression of phenylalanine ammonia-lyase and chalcone synthase during soybean nodule development. Plant Cell 3, 299-308.

Fehling C, Bassarab S, Werner D. 1992. High flavin/protein ratio in the symbiosome space of soybean nodules. Current Microbiology 25, 269-73

Felix G, Grosskopf DG, Regenass M, Boller T. 1991. Rapid changes of protein phosphorylation are involved in transduction of the elicitor signal in plant cells. Proceedings of the National Academy of Science, USA 88, 8831-4.

Felix G, Regenass M, Boller T. 1993. Specific perception of subnanomolar concentrations of chitin fragments by tomato cells: Induction of extracellular alkalinization, changes in protein phosphorylation and establishment of a refractory state. The Plant Journal 4, 307-16.

Firmin JL, Wilson KE, Rossen L, Johnston AWB. 1986 Flavonoid activation of nodulation genes in Rhizobium reversed by other compounds present in plants. Nature $324,90-2$.

Goodlass G, Smith KA. 1979. Effects of ethylene on root extension and nodulation of pea (Pisum sativum L.) and white clover (Trifolium repens L.). Plant and Soil 51, 387-95.

Gollotte A, Gianinazzi-Pearson V, Giovannetti M, Sbrana C, Avio L, Gianinazzi S. 1993. Cellular localization and cytochemical probing of resistance reactions to arbuscular mycorrhizal fungi in a 'locus $a$ ' $\mathrm{Myc}^{-}$mutant of Pisum sativum L. Planta 191, 112-22.

Göttfert M, Holzhäuser D, Bäni D, Hennecke H. 1992. Structural and functional analysis of two different nodD genes in Bradyrhizobium japonicum USDA 110. Molecular PlantMicrobe Interactions 3, 257-65.

Graham TL, Graham MY. 1991. Glyceollin elicitors induce major, but distinctly different, shifts in isoflavonoid metabolism in proximal and distal soybean cell populations. Molecular Plant-Microbe Interactions 4, 60-8.

Grosskopf E, Cam Ha DT, Wingender R, Röhrig H, Szecsi J, Kondorosi E, Schell J, Kondorosi A. 1993. Enhanced levels of chalcone synthase in alfalfa nodules induced by a Fix mutant of Rhizobium meliloti. Molecular Plant-Microbe Interactions 6, 173-81.

Halverson LJ, Stacey G. 1984. Host recognition in the Rhizobium-soybean symbiosis: Detection of a protein factor in soybean root exudate which is involved in the nodulation process. Plant Physiology 74, 84-9.

Hartwig UA, Maxwell CA, Joseph CM, Phillips DA. 1989. Interactions among flavonoid nod-gene inducers released from alfalfa seeds and roots. Plant Physiology 91, 1138-42.

Heckmann MO, Drevon JJ. 1988. Inhibition of symbiotic nitrogen fixation by nitrate. In: O'Gara F, Manian S, Drevon
$\mathrm{JJ}$, eds. Physiological limitations and the genetic improvement of symbiotic nitrogen fixation. Dordrecht: Kluwer, 97-106.

Hiltner L, Störmer K. 1903. Neue Untersuchungen über die Wurzelknöllchen der Leguminosen und deren Erreger. Arbeiten aus der biologischen Abtheilung für Land- und Forstwirtschaft am kaiserlichen Gesundheitsamte 3, 11-307.

Hirsch AM. 1992. Developmental biology of legume nodulation. New Phytologist 122, 211-37.

Hirsch AM, Bhuvaneswari TV, Torrey JG, Bisseling T. 1989. Early nodulin genes are induced in alfalfa root outgrowths elicited by auxin transport inhibitors. Proceedings of the National Academy of Science, USA 86, 1244-8.

Hotter GS, Scott DB. 1991. Exopolysaccharide mutants of Rhizobium meliloti are fully effective on a determinate nodulating host, but are ineffective on an indeterminate nodulating host. Journal of Bacteriology 173, 851-9.

Hubbell DH. 1970. Studies on the root hair 'curling factor' of Rhizobium. Botanical Gazette 131, 337-42.

Jacobs M, Rubery PH. 1988. Naturally occurring auxin transport regulators. Science 241, 346-9.

Jakobek JL, Lindgren PB. 1993. Generalized induction of defence responses in bean is not correlated with the induction of the hypersensitive reaction. Plant Cell 5, 49-56.

Kape R, Parniske M, Brandt S, Werner D. 1992. Isoliquiritigenin, a strong nod gene and glyceollin resistance inducing flavonoid from soybean root exudate. Applied Environmental Microbiology 58, 1705-10.

Karr DB, Emerich DW, Karr AL. 1992. Accumulation of the phytoalexin, glyceollin, in root nodules of soybean formed by effective and ineffective strains of Bradyrhizobium japonicum. Journal of Chemical Ecology 18, 997-1008.

Katinakis P, Klein-Lankhorst RM, Louwerse J, Van Kammen A, Van den Bos RC. 1988. Bacteroid-encoded proteins are secreted into the peribacteroid space by Rhizobium leguminosarum. Plant Molecular Biology 11, 183-90.

Klement Z. 1982. Hypersensitivity. In: Mount MS, Lacy GH, eds. Phytopathogenic prokaryotes. New York: Academic Press, 149-77.

Knight CD, Rossen L, Robertson JG, Wells B, Downie JA. 1986. Nodulation inhibition by Rhizobium leguminosarum multicopy nod $A B C$ genes and analysis of early stages of plant infection. Journal of Bacteriology 166, 552-8.

Kosslak RM, Bookland R, Barkei J, Paaren HE, Appelbaum ER. 1987. Induction of Bradyrhizobium japonicum common nod genes by isoflavones isolated from Glycine max. Proceedings of the National Academy of Science, USA 84, 7428-32.

Krishnan HB, Pueppke SG. 1993. Flavonoid inducers of nodulation genes stimulate Rhizobium fredii USDA 257 to export proteins into the environment. Molecular PlantMicrobe Interactions 6, 107-13.

Lee KH, LaRue TA. 1992a. Ethylene as a possible mediator of light- and nitrate-induced inhibition of nodulation of Pisum sativum L. cv. Sparkle. Plant Physiology 100, 1334-8.

Lee KH, LaRue TA. 1992b. Exogenous ethylene inhibits nodulation of Pisum sativum L. cv. Sparkle. Plant Physiology 100, 1759-63.

Leigh JA, Signer ER, Walker GC. 1985. Exopolysaccharidedeficient mutants of Rhizobium meliloti that form ineffective nodules. Proceedings of the National Academy of Science, USA 82, 6231-5.

Leigh JA, Walker GC. 1994. Exopolysaccharides of Rhizobium: synthesis, regulation and symbiotic function. Trends in Genetics 10, 63-7.

Lerouge P, Roche P, Faucher C, Maillet F, Truchet G, Prome J-C, Denarie J. 1990. Symbiotic host-specificity of Rhizobium 
melilot $i$ is determined by a sulphated and acylated glucosamine oligosaccharide signal. Nature 344, 781-4.

Lie TA. 1969. Non-photosynthetic effects of red and far-red light on root-nodule formation by leguminous plants. Plant and Soil 30, 391-404.

Long SR, Cooper J. 1988. Overview of symbiosis. In: Palacios R, Verma DPS, eds. Molecular genetics of plant-microbe interactions. St Paul: APS Press, 163-78.

Lucas J, Henriques AC, Lottspeich F, Henschen J, Sirpa HL. 1985. Amino acid sequence of the 'pathogenesis-related' protein p14 from viroid-infected tomato reveals a new type of structurally unfamiliar proteins. EMBO Journal 4, 2745-51.

Malik NSA, Pence MK, Calvert HE, Bauer WD. 1984. Rhizobium infection and nodule development in soybean are affected by exposure of the cotyledons to light. Plant Physiology 75, 90-4.

Mathews A, Carroll BJ, Gresshoff PM. 1987. Characterization of non-nodulating mutants of soybean (Glycine max $\mathbf{L}$. Merr.): Bradyrhizobium effects and absence of root hair curling. Journal of Plant Physiology 131, 349-61.

Mathews A, Carroll BJ, Gresshoff PM. 1989. Development of Bradyrhizobium infections in supernodulating and nonnodulating mutants of soybean (Glycine $\max \mathrm{L}$. Merrill). Protoplasma 150, 40-7.

Mauch F, Hadwiger LA, Boller T. 1988. Antifungal hydrolases in pea tissue. I. Purification and characterization of two chitinases and two beta-1,3 glucanases differentially regulated during development and in response to fungal infection. Plant Physiology 87, 325-33.

Maxwell CA, Harrison MJ, Dixon RA. 1993. Molecular characterization and expression of alfalfa isoliquiritigenin $2^{\prime}$ - $O$-methyltransferase, an enzyme specifically involved in the biosynthesis of an inducer of Rhizobium meliloti nodulation genes. The Plant Journal 4, 971-81.

Mellor RB, Rosendahl L. 1994. A soybean peribacteroid space component, riboflavin, represses daidzein-induced common nod-gene expression in Bradyrhizobium japonicum. Journal of Plant Physiology 144, 34-7.

Mergaert P, Van Montagu M, Prome JC, Holsters M. 1993. Three unusual modifications, an arabinosyl, an $\mathrm{N}$-methyl, and a carbamoyl group, are present on the Nod-factors of Azorhizobium caulinodulans strain ORS571. Proceedings of the National Academy of Science, USA 90, 1551-5.

Metraux J-P, Boller T. 1986. Local and systemic induction of chitinase in cucumber plants in response to viral, bacterial and fungal infections. Physiological and Molecular Plant Pathology 28, 161-9.

Meyer AD, Mellor RB. 1993. Nod active compounds in soybean nodules. Journal of Plant Physiology 142, 57-60.

Mohammadi M, Kart AL. 1993. The use of soybean plantlets to study root nodule senescence. Journal of Plant Physiology 141, 206-9.

Munns DN. 1968. Nodulation of Medicago sativa in solution culture. III. Effects of nitrate on root hairs and infections. Plant and Soil 29, 33-47.

Neuhaus J-M, Ahl-Goy P, Hinz U, Flores S, Meins F. 1991. High-level expression of a tobacco chitinase gene in Nicotiana sylvestris. Susceptibility of transgenic plants to Cercospora nicotianae infection. Plant Molecular Biology 16, 141-51.

Newman EI, Reddell P. 1987. The distribution of mycorrhizae among families of vascular plants. New Phytologist 106, $745-51$.

Nicholson RL, Hammerschmidt R. 1992. Phenolic compounds and their role in disease resistance. Annual Review of Phytopathology 30, 369-89.

Niehaus K, Kapp D, Pahler A. 1993. Plant defence and delayed infection of alfalfa pseudonodules induced by an exopolysaccharide (EPS I)-deficient Rhizobium meliloti mutant. Planta 190, 415-25

Nielsen KK, Bojsen K, Collinge DB, Mikkelsen JD. $1994 b$. Induced resistance in sugar beet against Cercospora beticola: induction by dichlorisonicotinic acid is independent of chitinase and beta-1,3 glucanase transcript accumulation. Physiological and Molecular Plant Pathology 45, 89-99.

Nielsen KK, Bojsen K, Roepstorff P, Mikkelsen JD. 1994a. A hydroxyproline-containing class IV chitinase of sugar beet is glycosylated with xylose. Plant Molecular Biology 25, 241-57.

Nieksen KK, Mikkelsen JD, Kragh KM, Bojsen K. 1993. An acidic class III chitinase from sugar beet: Induction by Cercospora beticola, characterization and expression in transgenic tobacco plants. Molecular Plant-Microbe Interactions 6, 495-506.

Oku H, Shiraishi T, Kato T, Kim HM, Saitoh K, Tahara M. 1993. Structure and mode of action of suppressors, pathogenicity factors of the pea pathogen Mycosphaerella pinodes. In: Fritig B, Legrand M, eds. Mechanisms of plant defence responses. Dordrecht: Kluwer.

Osman SF, Fett WF. 1983. Isoflavone glucoside stress metabolites of soybean leaves. Phytochemistry 22, 1921-3.

Ouchi S. 1983. Induction of resistance or susceptibility. Annual Review of Phytopathology 21, 289-315.

Paau AS, Cowles JR. 1981. Bacteroid distributions in alfalfa nodules upon dark-induced senescence and subsequent partial rejuvenation. Physiologia Plantarum 52, 43-6.

Pankhurst CE, Schwinghammer EA, Thorne SW, Bergersen FJ. 1974. The flavin content of clovers relative to symbiosis with a riboflavin-requiring mutant of Rhizobium trifolii. Plant Physiology 53, 198-205.

Parniske M, Ahlborn B, Werner D. 1991. Isoflavonoid-inducible resistance to the phytoalexin glyceollin in soybean rhizobia. Journal of Bacteriology 173, 3432-9.

Perotto S, Brewin NJ, Kannenberg EL. 1994. Cytological evidence for a host defence response that reduces cell and tissue invasion in pea nodules by lipopolysaccharide-defective mutants of Rhizobium leguminosarum strain 3841. Molecular Plant-Microbe Interactions 7, 99-112.

Peters NK, Long SR. 1988. Alfalfa root exudates and compounds which promote or inhibit induction of Rhizobium meliloti nodulation genes. Plant Physiology 88, 396-400.

Philip-Hollingsworth S, Hollingsworth RI, Dazzo FB, Djordjevic MA, Rolfe BG. 1989. The effect of interspecies transfer of Rhizobium host-specific nodulation genes on acidic polysaccharide structure and in situ binding by host lectin. Journal of Biological Chemistry 264, 5710-14.

Phillips DA. 1992. Flavonoids: plant signals to soil microbes. In: Stafford HA, Ibrahim RK, eds. Recent advances in phytochemistry, Vol. 26, Phenolic metabolism in plants. New York: Plenum Press, 201-31.

Phillips DA, Hartwig UA, Maxwell CA, Joseph CM, Wery J, Hungria M, Tsai SM. 1990. Host legume control of nodulation by flavonoids. In: Gresshoff PM, Roth LE, Stacey G, Newton WE, eds. Nitrogen fixation: achievements and objectives. New York, London: Chapman and Hall, $331-8$.

Pierce M, Bauer WB. 1983. A rapid regulatory response governing nodulation in soybean. Plant Physiology 73, 286-90.

Recourt K, van Tunen AJ, Mur LA, van Brussel AAN, Lugtenberg BJJ, Kijne JW. 1992. Activation of flavonoid biosynthesis in roots of Vicia sativa subsp. nigra plants by inoculation with Rhizobium leguminosarum biovar viciae. Plant Molecular Biology 19, 411-20. 
Robinette D, Matthysse AG. 1990. Inhibition by Agrobacterium tumifaciens and Pseudomonas savastanoi of development of the hypersensitive response elicited by Pseudomonas syringae pv. phaseolicola. Journal of Bacteriology 172, 5742-9.

Roche P, Lerouge P, Ponthus C, Prome J-C. 1991. Structural determination of bacterial nodulation factors involved in the Rhizobium meliloti-alfalfa symbiosis. Journal of Biological Chemistry 266, 10933-40.

Rudin PE. 1956. Versuche zur Physiologie der Knöllchenbildung bei Pisum sativum L. Phytopathologische Zeitschrift 26, 57-80.

Salzwedel JL, Dazzo FB. 1993. pSym nod gene influence on elicitation of peroxidase activity from white clover and pea roots by rhizobia and their cell-free supernatants. Molecular Plant-Microbe Interactions 6, 127-34.

Sanjuan J, Carlson RW, Spaink HP, Bhat UR, Barbour WM, Ghushka J, Stacey G. 1992. A 2- $O$-methylfucose moiety is present in the lipo-oligosaccharide nodulation signal of Bradyrhizobium japonicum. Proceedings of the National Academy of Science USA, 89, 8789-93.

Savoure A, Magyar Z, Pierre M, Brown S, Schultze M, Dudits D, Kondorosi A, Kondorosi E. 1994. Activation of the cell cycle machinery and the isoflavonoid biosynthesis pathway by active Rhizobium meliloti Nod signal molecules in Medicago microcallus suspensions. EMBO Journal 13, 1093-102.

Schlaman HRM, Horvath B, Vijgenboom E, Okker RJH, Lugtenberg BJJ. 1991. Suppression of nodulation gene expression in bacteroids of Rhizobium leguminosarum biovar viciae. Journal of Bacteriology 173, 4277-87.

Schlaman HRM, Lugtenberg BJJ, Okker RJH. 1992. The NodD protein does not bind to the promoters of inducible nodulation genes in extracts of bacteroids of Rhizobium leguminosarum biovar viciae. Journal of Bacteriology 174, 6109-16.

Schmidt PE, Parniske M, Werner D. 1992. Production of the phytoalexin glyceollin 1 by soybean roots in response to symbiotic and pathogenic infection. Botanica Acta 105, 18-25.

Schultze M, Kondorosi E, Kondorosi A, Staehelin C, Mellor RB, Boller T. 1993. The sulphate group on the reducing end protects Nod signals of Rhizobium meliloti against hydrolysis by Medicago chitinases. In: Palacios R, Mora J, Newton WE, eds. New horizons in nitrogen fixation. Dordrecht: Kluwer, 159-64.

Schultze M, Quiclet-Sire B, Kondorosi E, Virelizier H, Glushka JN, Endre G, Gero SD, Kondorosi A. 1992. Rhizobium meliloti produces a family of sulphated lipo-oligosaccharides exhibiting different degrees of plant host specificity. Proceedings of the National Academy of Sciences, USA 89, 192-6.

Spaink HP, Sheeley DM, van Brussel AAN, Glushka J, York WS, Tak T, Geiger O, Kennedy EP, Reinhold VN, Lugtenberg BJJ. 1991. A novel highly unsaturated fatty acid moiety of lipo-oligosaccharide signals determines host specificity of Rhizobium. Nature 354, 125-30.

Staehelin C, Granado J, Móller J, Mellor RB, Wiemken A, Felix G, Boller T. 1992b. Different legume chitinases differ in their ability to hydrolyse nodulation factors of rhizobia. Physiologia Plantarum 85, A41.

Staehelin C, Granado J, Maller J, Wiemken A, Mellor RB, Felix G, Regenass M, Broughton WJ, Boller T. 1994a. Perception of Rhizobium nodulation factors by tomato cells and inactivation by root chitinases. Proceedings of the National Academy of Sciences, USA 91, 2196-200.

Staehelin C, Muller J, Mellor RB, Wiemken A, Boller T. $1992 a$. Chitinase and peroxidase in effective $\left(\mathrm{fix}^{+}\right)$and ineffective $\left(\right.$ fix $\left.^{-}\right)$soybean nodules. Planta 187, 295-300.

Staehelin C, Schultze M, Kondorosi E, Mellor RB, Boller T,
Kondorosi A. 1994b. Structural modifications in Rhizobium meliloti Nod factors influence their stability against hydrolysis by chitinase. The Plant Journal 5, 319-30.

Stokkermans TJW, Peters NK. 1994. Bradyrhizobium elkani lipo-oligosaccharide signals induce complete nodule structures on Glycine soja Siebold et Zucc. Planta 193, 413-20.

Stougaard J. 1993. Substrate-dependent negative selection in plants using a bacterial cytosine deaminase gene. The Plant Journal 3, 755-61.

Streeter JG. 1986. Effect of nitrate on acetylene reduction activity and carbohydrate composition of Phaseolus vulgaris nodules. Physiologia Plantarum 68, 294-300.

Streeter JG. 1988. Inhibition of legume nodule formation and $\mathrm{N}_{2}$ fixation by nitrate. CRC Critical Reviews in Plant Science 7, 1-23.

Sturtevant DB, Taller BJ. 1989. Cytokinin production by Bradyrhizobium japonicum. Plant Physiology 89, 1247-52.

Svalheim A, Robertsen B. 1990. Induction of peroxidases in cucumber hypocotyls by wounding and fungal infection. Physiologia Plantarum 78, 261-7.

Tanner JW, Anderson IC. 1964. External effect of combined nitrogen on nodulation. Plant Physiology 39, 1039-43.

Thanh Van KT, Toubart P, Cousson A, Darvill AG, Gollin DJ, Chelf P, Albersheim P. 1985. Manipulation of the morphogenetic pathways of tobacco explants by oligosaccharins. Nature 314, 615-17.

Thomas MR, Rose RJ, Nolan KE. 1992. Genetic transformation of Medicago truncatula using Agrobacterium with genetically modified Ri and disarmed Ti plasmids. Plant Cell Reporter 11, 113-17

Thomton HG. 1936. Action of sodium nitrate on infection of lucerne root hairs by nodule bacteria. Proceedings of the Royal Society London, Series B, 119, 47-92.

Truchet $G$, Roche $P$, Lerough $P$, Vasse J, Camut $S$, de Billy $F$, Prome JC, Denarie J. 1991. Sulphated lipo-oligosaccharide signals of Rhizobium meliloti elicit root nodule organogenesis in alfalfa. Nature 351, 670-3.

Turgeon BG, Bauer WD. 1982. Early events in the infection of soybean by Rhizobium japonicum. Time-course and cytology of the initial infection process. Canadian Journal of Botany 60, 152-61.

Van Brussel AAN, Tak T, Wijfjes AHM, Spaink HP, Smit G, Diaz CL, Kijne JW. 1993. Jamming of nodulation of Vicia sativa spp. nigra by Nod-factors of Rhizobium leguminosarum bv viciue. In: Palacios R, Mora J, Newton WE, eds. New horizons in nitrogen fixation. Dordrecht: Kluwer.

VandenBosch KA, Rodgers LR, Sherrier DJ, Kishinevsky BD. 1994. A peanut nodule lectin in infected cells and in vacuoles and the extracellular matrix of nodule parenchyma. Plant Physiology 104, 327-37.

Vasse J, de Billy F, Truchet G. 1993. Abortion of infection during the Rhizobium meliloti-alfalfa symbiotic interaction is accompanied by a hypersensitive reaction. The Plant Journal 4, 555-66.

Verma DPS. 1992. Signals in root nodule organogenesis and endocytosis of Rhizobium. Plant Cell 4, 373-82.

Vierheilig H, Alt M, Neuhaus J-M, Boller T, Wiemken A. 1993. Colonization of transgenic Nicotiana sylvestris plants, expressing different forms of Nicotiana tabacum chitinase, by the root pathogen Rhizoctonia solani and by the mycorrhizal symbiont Glomus mosseae. Molecular Plant-Microbe Interactions 6, 261-4.

Vignutelli A. 1991. Der Einfluss von Ethylen und Elicitoren auf die Chitinaseaktivität und symbiotische Stickstoff-Fixierung von Glycine max, Phaseolus vulgaris und Pisum sativum. Diplomarbeit, University of Basel. 
Vijn I, das Neves L, van Kammen A, Franssen H, Bisseling T. 1993. Nod factors and nodulation in plants. Science 260, 1764-5.

Wang TL, Wood EA, Brewin NJ. 1982. Growth regulators and nodulation in peas: The cytokinin content of a wild-type and a Ti plasmid-containing strain of Rhizobium leguminosarum. Planta 155, 350-5.

Weinstein LI, Hahn MG, Albersheim P. 1981. Host-pathogen interactions. XVIII. Isolation and biological activity of glycinol, a pterocarpan phytoalexin synthesized by soybeans. Plant Physiology 68, 358-63.

Welters P, Metz B, Felix G, Palme K, Szczyglowski K, de Bruijn FJ. 1993. Interaction of a rhizobial DNA-binding protein with the promoter region of a plant leghemoglobin gene. Plant Physiology 102, 1095-1 107.

Werner D, Mellor RB, Hahn M, Grisebach H. 1985. Soybean root response to symbiotic infection: Glycoellin I accumulation in an ineffective type of soybean nodule with an early loss of the peribacteroid membrane. Zeitschrift für Naturforschung 40c, 179-81.
Williams LF, Lynch DL. 1954. Inheritance of a non-nodulating character in the soybean. Agronomy Journal 46, 28-9.

Wingender R, Röhrig H, Höricke C, Wing D, Schell J. 1989. Differential regulation of soybean chalcone synthase genes in plant defence, symbiosis, and upon environmental stimuli. Molecular and General Genetics 218, 315-22.

Wyss P, Mellor RB, Wiemken A. 1990. Vesicular-arbuscular mycorrhizas of wild-type soybean and non-nodulating mutants with Glomus mosseae contain symbiosis-specific polypeptides (mycorrhizins), immunologically cross-reactive with nodulins. Planta 182, 22-6.

Yang W-C, Canter-Cremers HCJ, Hodendijk P, Katinakis P, Wijffelman CA, Franssen $\mathrm{H}$, Van Kammen A, Bisseling $\mathrm{T}$. 1992. In situ localization of chalcone synthase mRNA in pea root nodule development. The Plant Journal 2, 143-51.

Yao PY, Vincent JM. 1976. Factors responsible for the curling and branching of clover root hairs by Rhizobium. Plant and Soil 45, 1-16. 